\title{
Experimental Urolithiasis Model to assess Phyto-fractions as Anti-lithiatic Contributors: A Herbaceutical Approach
}

\begin{abstract}
Aishwarya Tripurasundari Devi ${ }^{1}$, Yashaswini ${ }^{1}$, Farhan Zameer ${ }^{24 *}$, Nagendra Prasad MN1T*

${ }^{1}$ Department of Biotechnology, JSS Science and Technology University, JSS Research Foundation, SJCE Campus, Manasagangotri, Mysore - 560 006, Karnataka, India.

${ }^{2}$ PathoGutOmic Laboratory, Department of Biochemistry, School of Basic and Applied Sciences, Dayananda Sagar University, Shavige Malleshwara Hills, Kumaraswamy Layout, Bengaluru - 560 111, Karnataka, India.
\end{abstract}

I Both the authors share the corresponding authorship for equal contribution.

*Corresponding author 1: Dr. Nagendra Prasad MN: Professor \& Head, Department of Biotechnology, JSS Science and Technology University, JSS Research Foundation, SJCE Campus, Manasagangotri, Mysore - 560 006, Karnataka, India.

Phone no: 0091-9886480528

Email: mnnagendraprasad@sjce.ac.in

*Corresponding author 2: Dr. Farhan Zameer: Assistant Professor in Biochemistry, PathoGutOmic Laboratory, School of Basic and Applied Sciences, Department of Biological Sciences, Dayananda Sagar University, Shavige Malleshwara Hills, Kumaraswamy Layout, Bengaluru - 560 111, Karnataka, India.

Phone no: 0091-9844576378

Email: farhanzameeruom@gmail.com 


\begin{abstract}
Life-style disorders have bought a serious burden on the maintenance of health in animals and humans. Lithiasis specifically nephro- and urolithiasis is no exception and needs urgent attention. Currently, only semi-invasive and surgical methods are widely employed which leads to trauma and reoccurrence of kidney stones. Hence complementary and alternative herbal medicine could pave newer ways in exploring anti-lithiatic contributors. The current study attempts to screen twenty herbal hot aqueous leaf extracts for assessing their antioxidant potency (anti-stress) and efficiency against urolithiasis in an experimental calcium oxalate-induced in vitro (chicken egg membrane) model. The study was further validated by In silico molecular docking studies using the Molegro software package on enzymatic biomarkers involved in scavenging oxidants in the host and regulating oxalate metabolism at a cellular level. Among the screened botanicals Kalanchoe pinnata exhibited promising results compared to the standard chemical (potassium-magnesium citrate) and phyto-formulation drug (cystone) currently used by clinicians for treating urolithiasis. The phytochemical profiling (qualitative and quantitative) and virtual studies indicated rutin from Kalanchoe pinnata as a potential candidate for preventing kidney stones. The results of the current study provide better insights into the design and development of newer, smart, and cost-effective herbal therapeutics making food as medicine.
\end{abstract}

Keywords: Lithiasis, Kidney stones, Calcium oxalate, Biomarkers, Anti-stress, Structureactivity relationship (SAR) Studies, Botanicals, Kalanchoe pinnata, Phyto-pharmaceutics 


\section{Introduction}

Food and health are the two integral components of human wellbeing. However, in the urge of adapting to newer technologies and advanced niches both these components are highly neglected. In consequence, many lifestyle, non-communicative disorders, or diseases has become a part of human health. Indian folklore medicine and Ayurveda proposes the implications of "food as medicine" from time immemorial. Further, complementary and alternative medicine (CAM) has been successful in exploring the scientific proof and mechanism of actions of these phyto-formulations leading to the development of newer drug targets and therapeutics. Phyto-cocktails are effective in many complications from venom antidots (Janardhan et al., 2019; Vineetha et al., 2020, Bhavya et al., 2021), neurodegenerative disorders (Kunnel et al., 2019; Satapathy et al., 2020), diabetes (Putta et al., 2016), ulcers (Prasad et al., 2019), cancer (Rakesh et al., 2015), infection (Zameer et al., 2016) to inflammation (Rakesh et al., 2016). With all the set examples from our previous studies, one major disorder caught our attention which was a common lifestyle disorder yet very painful, which had no structured therapy and was found in folks of all ages but most prevalent in men known as lithiasis (stone formation).

Lithiasis is a condition in which the formation of stones or calculi is observed due to the concentration of mineral salts (Grases et al., 2007). The kidney, urinary tract, pancreas, and gallbladder are the most commonly affected organs by lithiasis, and they are categorized based on their site of formation leading to nephrolithiasis, urolithiasis, pancreatolithiasis, and cholecystolithiasis respectively (Tatapudi et al., 2020). Stones containing calcium are a common type of calculi with a prevalence of $70-80 \%$, of which calcium phosphate and calcium oxalate dominate (Han et al., 2015). Supersaturation of urine in presence of calcium and oxalate facilitates calcium oxalate stone development (Paliouras et al., 2012). Following are the factors which affect the formation of calcium oxalate stones; acidic urine, low volume of urine, hypercalciuria (increased concentration of calcium in urine leads to precipitation of calcium salts), hyperoxaluria (high concentration of oxalate excreted in urine), hypocitraturia (excretion of a lower amount of citrate in urine which leads to high $\mathrm{pH}$ ) and hyperuricosuria (acidic urine dissolves uric acid, leading to stone formation). Apart from calcium, magnesium phosphate, uric acid, cysteine, silica, xanthine, and 2, 8-dihydroxyadenine also account for the stone formation (Moe et al., 2006; Evan et al., 2015). Further, with all the above understanding of biochemistry and pathophysiology of urolithiasis, an optimized and 
standardized model system is a prime necessity that should be rapid, reliable, and reproducible. To serve this purpose, the chicken egg membrane model was employed to study the dissolution of calcium oxalate with nucleation and aggregation assessments (Phatak and Hendre, 2015). Indian traditional system of medicine (Ayurveda) strongly emphasizes the use of phyto-formulations for almost any ailments and urolithiasis, is no exception. Hence an attempt was made to explore the less exploited plants as anti-urolithiatic agents (table 1).

Further, phytobioactives in different forms crude, partially purified, purified, or in cocktails play a vital role either as a single drug or complex provide synergy in ameliorating health complications from a simple infection, inflammation to a cascade of disorders/diseases (Aishwarya et al., 2020). These various activities are mainly due to the different classes of phytochemicals predominately secondary metabolites of polyphenolic umbrella namely phenolics, flavonoids, alkaloids, terpenoids, tannins, saponins, and sterols (Pankaj et al., 2020; Khan et al., 2020). According to Gulcin (2020), a detailed correlation of phytochemicals with antioxidant efficacy is well illustrated and this property could be explored for stress and inflammation which is usually encountered during urolithiasis. Apart from the antioxidant phytobioactives, enzymatic biomarkers such as catalase (CAT), superoxide dismutase (SOD), peroxidase (PER), glutathione S-transferase (GST), contribute against redox reaction, stress, and inflammation respectively (Gopal et al., 2009). Besides, metabolic enzymes such as alanine-glyoxlate aminotransferase, oxalyl-coA decarboxylase, D-glycerate dehydrogenase, and lactate dehydrogenase (LDH) regulate a crucial role in stone formation (Ramu et al., 2017). Elucidation of the mechanism of action of these biomarkers in urolithiasis is very much essential. Structure-activity relationship (SAR) studies were employed to decipher the above set objective using molecular docking studies (Madhusudhan et al., 2016).

Henceforth, in the current study, an attempt has been employed to profile phytochemicals (qualitative), to evaluate the antioxidant potency, and to adapt a simple experimental model for kidney stones (chicken egg membrane) to screen anti-urolithiatic effect (in vitro) of selected 20 plants (aqueous extracts) supported by the in silico evaluation for proof-of-concept in search of highly-efficient and cost-effective herbaceuticals to ameliorate urolithiasis.

\section{Materials \& Methods}


All chemicals, solvents, and reagents used for the study were of analytical grade and were purchased from Himedia Pvt. Ltd, Mumbai, India. The standard drug Cystone ${ }^{\circledR}$ was purchased from Himalaya Drug Company, Bangalore, India. Unfertilized chicken eggs were procured from local poultry in Mysuru and membranes were isolated.

Plant material: Twenty different medicinal plant leaves (table 1) were collected from in and around Mysuru, India, from March to July 2018. Further, the plants were authenticated and are deposited at the herbarium center, Department of Studies in Botany, University of Mysore, Karnataka. The leaves of Aegle marmelos, Apium graveolens, Artocarpus heterophyllus, Azadirachta indica, Citrus limon, Citrus sinensis, Coriandrum sativum, Cucumis sativus, Kalanchoe pinnata, Lawsonia inermis, Mangifera indica, Manilkara zapota, Momordica charantia, Moringa oleifera, Musa paradisiaca, Phyllanthus emblica, Plectranthus amboinicus, Psidium guajava, Punica granatum and Ribes Uva-crispa were harvested, leaves were surface sterilized and dried in a hot air oven at $45^{\circ} \mathrm{C}$ for 48 hours and powdered to 60 mesh packed in an air-tight container until further experimentation.

For extraction: The hot aqueous extract was prepared for all the twenty plants, $20 \mathrm{~g}$ of finely powdered leaves of the individual plant were mixed with $100 \mathrm{~mL}$ of distilled water ( $\mathrm{pH} 5.8$ ) and kept over a magnetic stirrer for 3 hours with a constant heat around $50 \pm 2{ }^{\circ} \mathrm{C}$ (Meghashri et al., 2011). Only aqueous extracts were targeted in the study, intending to isolate polar/hydrophilic phyto-molecules which will be much more practical to suggest patients with urological complications as a homemade decoction. Muslin cloth was used to filter; later, the filtrate was subjected to centrifugation for $10 \mathrm{~min}$ at $8000 \mathrm{rpm}$, after which the supernatant was collected and stored in a freezer for further use.

\section{Phytochemical analysis}

All the qualitative phytochemical profiling was performed according to the AOAC method (Shameh et al., 2018) and is represented in supplementary table 1.

\section{Estimation of total phenol content (TPC)}

All aqueous plant extracts were assessed by Folin-Ciocalteau (FC) method with a slight modification (Meghashri et al., 2010). Briefly, various volumes of the extracts were made up to $3 \mathrm{~mL}$ with distilled water. Folin-Ciocalteau reagent of (1:1 diluted) $0.5 \mathrm{~mL}$ was added and incubated for $5 \mathrm{~min}$ at room temperature, $1.5 \mathrm{~mL}$ of sodium carbonate $(20 \%)$ was 
added followed by incubation in a boiling water bath for $5 \mathrm{~min}$. The absorbance was measured at $640 \mathrm{~nm}$. Gallic acid $(1 \mathrm{mg} / \mathrm{mL})$ equivalents were used as the standard to estimate the phenolic content.

\section{Assessment of In vitro antioxidant activities for aqueous phyto-fractions:}

\section{DPPH free radical scavenging assay}

The free radical scavenging activity of all the plant extracts was measured by the DPPH (1,1-diphenyl-2picrylhydrazyl) method (Meghashri et al., 2010). Varied concentrations of the extracts [ $5 \mu \mathrm{g} / \mathrm{mL}, 10 \mu \mathrm{g} / \mathrm{mL}, 15 \mu \mathrm{g} / \mathrm{mL}, 20 \mu \mathrm{g} / \mathrm{mL}$, and $25 \mu \mathrm{g} / \mathrm{mL}$ of gallic acid equivalent] followed by $1 \mathrm{~mL}$ of DPPH solution, shaken and was incubated at room temperature for $20 \mathrm{~min}$ in the dark after which absorbance was measured at $517 \mathrm{~nm}$. Gallic acid was used as standard. The activity of the radical scavenging was calculated by the following equation:

Radical scavenging activity $(\%)=\left[\left(\mathrm{A}_{\text {control }}-\mathrm{A}_{\text {sample }}\right) / \mathrm{A}_{\text {control }}\right] \times 100$ (Where $\mathrm{A}=$ absorbance $)$

\section{Metal ion chelating assay}

The complex ferrous iron - ferrozine can chelate $\mathrm{Fe}^{2+}$, which can be observed at 562 $\mathrm{nm}$ (Meghashri et al., 2010). Different concentrations of all extracts were taken, $50 \mu \mathrm{L}$ of $\mathrm{FeCl}_{2}$ and $200 \mu \mathrm{L}$ of ferrozine were mixed and incubated at room temperature in the dark for $10 \mathrm{~min}$; finally, absorbance at $562 \mathrm{~nm}$ against blank was measured. The same equation used in DPPH scavenging activity is used here to know the capacity of the extract in cheating ferrous ions with EDTA considered as standard.

\section{Reducing power assay}

Reduction of iron (III) by the extracts was measured with slight modification (Nedamani et al., 2015) by adding the various concentration of all extracts and made up the volume to $500 \mu \mathrm{L}$ with phosphate buffer $(20 \mathrm{mM})$ and then $500 \mu \mathrm{L}$ of sodium ferricyanide (1\%) was added and incubated at $50^{\circ} \mathrm{C}$ for $20 \mathrm{~min} .500 \mu \mathrm{L}$ of trichloroacetic acid $(10 \%)$ was added to the solution to terminate the reaction followed by 10 min centrifugation. Finally, 1.5 $\mathrm{mL}$ of distilled water along with $300 \mu \mathrm{L}$ of ferric chloride $(0.1 \%)$ was added to the supernatant, and absorbance at 700nm was measured using gallic acid as standard. 


\section{Anti-lithiatic activity}

The anti-lithiatic activity was assessed for all the extracts according to Phatak and Hendre, (2015). Calcium chloride $(25 \mathrm{mM}) 1 \mathrm{~mL}$ of the solution was mixed with $2 \mathrm{~mL}$ of tris buffer ( $\mathrm{pH}$ 7.4). Water was considered as control, and extracts were added to the above mixture; finally, in the end, $1 \mathrm{~mL}$ of sodium oxalate $(25 \mathrm{mM})$ was added, and the clock was started. Absorbance at $620 \mathrm{~nm}$ for $10 \mathrm{~min}$ was measured and a standard graph.

\section{Preparation of semi-permeable membrane from chicken eggs}

Among the 20 extracts screened, only the top five extracts (Kalanchoe pinnata, Musa paradisiaca, Punica granatum, Coriandrum sativum, and Moringa oleifera) were used for further in vitro anti-lithiatic egg membrane assay. The complete content of the eggs was removed by piercing with a glass rod on top of the eggs. Then these eggs were washed carefully with distilled water and were immersed in a beaker containing $2 \mathrm{~N}$ HCL overnight for decalcification. The following day the semi-permeable membrane was cautiously removed from the shells rinsed with distilled water and neutralized with ammonia solution to remove any traces of acid from the membranes and finally rinsed with distilled water. Further, it was refrigerated at $\mathrm{pH}$ 7-7.4 condition to maintain moisture (Phatak and Hendre, 2015).

\section{Synthesis of calcium oxalate through homogenous precipitation}

Calcium chloride dihydrate weighing $1.47 \mathrm{~g}$ was dissolved using $100 \mathrm{~mL}$ of distilled water, and $100 \mathrm{~mL}$ of $2 \mathrm{~N} \mathrm{H}_{2} \mathrm{SO}_{4}$ was used to dissolve $1.34 \mathrm{~g}$ of sodium oxalate. Calcium oxalate starts precipitating with constant stirring when both the above solutions are mixed. Traces of sulphuric acid is removed by rinsing with ammonia solution and then finally rinsed with distilled water and kept for drying at $60^{\circ} \mathrm{C}$ for 4 hours (Monika et al., 2012). Calcium oxalate $1 \mathrm{mg} / \mathrm{mL}$ served as a negative control and a Cystone concentration of $20 \mathrm{mg} / \mathrm{mL}$ was set as a positive control (Phatak and Hendre, 2015). Further, the experimental groups were as follows, Negative control: $1 \mathrm{~mL}$ calcium oxalate $+1 \mathrm{~mL}$ of distilled water, Positive control: 1 $\mathrm{mL}$ of calcium oxalate $+1 \mathrm{~mL}$ of Cystone solution, Kalanchoe pinnata: $1 \mathrm{~mL}$ of calcium oxalate $+500 \mu \mathrm{L}$ of extract, Punica granatum: $1 \mathrm{~mL}$ of calcium oxalate $+500 \mu \mathrm{L}$ of extract, Musa paradisiaca: $1 \mathrm{~mL}$ of calcium oxalate $+500 \mu \mathrm{L}$ of extract, Coriandrum sativum: $1 \mathrm{~mL}$ of calcium oxalate $+500 \mu \mathrm{L}$ of extract and Moringa oleifera: $1 \mathrm{~mL}$ of calcium oxalate +500 $\mu \mathrm{L}$ of extract respectively. 
The above-mentioned groups consisting of both positive and negative controls along with extracts were packed into respective semi-permeable membranes further the mouth of the membrane was tied with the help of thread and was immersed in a conical flask containing $100 \mathrm{~mL}$ of $0.1 \mathrm{M}$ tris buffer. Incubator was preheated for 2 hours to obtain a constant temperature of $37^{\circ} \mathrm{C}$; all the groups were placed inside the incubator for $7-8$ hours (Phatak and Hendre, 2015). The contents of each group were transferred into a fresh flask, and $2 \mathrm{~mL}$ of $1 \mathrm{~N}$ sulphuric acid was added and was titrated against $0.9494 \mathrm{~N} \mathrm{KMnO}_{4}$ till the endpoint that is light pink color is observed. Percentage dissolution was calculated based on titration (Monika et al., 2012). Based on these results the best aqueous extract exhibiting antilithiatic activity was found to be Kalanchoe pinnata and further studies focused on this single phyto-fraction only.

\section{Standard curve of calcium oxalate}

Potassium permanganate $3.2 \mathrm{~g}$ was dissolved in $1000 \mathrm{~mL}$ of distilled water and then boiled for $30 \mathrm{~min}$. Later, filtered using Whatman filter paper to obtain $0.02 \mathrm{M}$ of $\mathrm{KMnO}_{4}$. Different concentrations of calcium oxalate $(0.2 \mathrm{mg} / \mathrm{mL}, 0.4 \mathrm{mg} / \mathrm{mL}, 0.6 \mathrm{mg} / \mathrm{mL}, 0.8 \mathrm{mg} / \mathrm{mL}$, and $1 \mathrm{mg} / \mathrm{mL}$ ) was used and the volume to $1 \mathrm{~mL}$ using distilled water. A $4 \mathrm{~mL}$ of sulphuric acid was added with $80 \mu \mathrm{L}$ of $0.02 \mathrm{M} \mathrm{KMnO}_{4}$. The above mixture was mixed well and incubated for 2 hours after which absorbance was read using a spectrophotometer at $620 \mathrm{~nm}$. For all further analyses, only the best extract (Kalanchoe pinnata) was intervened to deduce the probable mechanism of calcium oxalate dissolution.

\section{Nucleation assay}

The nucleation of calcium oxalate crystals was estimated using a spectrophotometer, and Kalanchoe pinnata inhibiting potency was determined by the method of Saha and Verma (2013), with minor alteration. Calcium chloride $4 \mathrm{mmol} / \mathrm{L}$ and sodium oxalate $50 \mathrm{mmol} / \mathrm{L}$ were mixed to initiate crystallization, and this was added to artificial urine. The solutions were prepared in Tris $0.05 \mathrm{~mol} / \mathrm{L}$ for calcium chloride and $\mathrm{NaCl} 0.15 \mathrm{~mol} / \mathrm{L}$ at $\mathrm{pH} 6.5$ and $37^{\circ} \mathrm{C}$ for sodium oxalate. Nucleation rate was obtained by equating the time of crystal formation about the presence of varying concentrations of Kalanchoe pinnata and with no extract in another and also Cystone was used as the positive control, absorbance was recorded at 1 hour, 3 hours, and 24 hours at $620 \mathrm{~nm}$, percentage inhibition was calculated accordingly. 


\section{Aggregation assay}

Saha and Verma (2013) method was tailored slightly to obtain the rate of aggregation of crystals of calcium oxalate. Calcium chloride and sodium oxalate $50 \mathrm{mmol} / \mathrm{L}$ solutions were mixed to obtain COM crystals. The two solutions were equalized by incubating in a water bath at $60^{\circ} \mathrm{C}$ for 1 hour and then brought to $37^{\circ} \mathrm{C}$ followed by evaporation. These crystals were brought to a concentration of $1 \mathrm{mg} / \mathrm{mL}$ by dissolving in $0.05 \mathrm{~mol} / \mathrm{L}$ Tris and $0.15 \mathrm{~mol} / \mathrm{L} \mathrm{NaCl}$ at $6.5 \mathrm{pH}$. Different concentrations of Kalanchoe pinnata were used along with negative control and positive control being Cystone were observed under a light microscope.

\section{RBC protection assay by Kalanchoe pinnata extract}

Consent from the healthy individual to procure erythrocytes was taken. The blood which was heparinized was centrifuged for $15 \mathrm{~min}$ at $1000 \mathrm{~g}$ through which the buffy coat and plasma were separated, and the erythrocytes with the help of PBS were rinsed thrice at room temperature reintroduced into PBS for further analysis, and the volume was made up four times. For $5 \mathrm{~min}$, Kalanchoe pinnata was incubated with erythrocytes and then further incubated for 1 hour at $37^{\circ} \mathrm{C}$ with hydrogen peroxide, ferric chloride, and ascorbic acid and kept in a shaker incubator for incubation and was observed under an optical microscope for any changes in the morphology (Beulah et al., 2015).

\section{DNA protection assay by Kalanchoe pinnata extract}

Protocol from Meghashri et al., (2010) with slight variations was adapted to check the efficacy of Kalanchoe pinnata in protecting the DNA was checked using lambda phage DNA (Meghashri et al., 2010). In the presence or lack of Kalanchoe pinnata and gallic acid, the oxidation with the help of Fenton's reagent along with lambda DNA was estimated for 2 hours at $37^{\circ} \mathrm{C}$. Electrophoresis was performed for the samples using $1 \%$ agarose gel at $50 \mathrm{~V}$ DC for 2 hours and stained the gels using ethidium bromide and visualized using gel documentation.

\section{High-Performance Liquid Chromatography (HPLC) Profiling}

The crude aqueous fraction, a hot extract of Kalanchoe pinnata was subjected to HPLC in a C-18 column with different mobile phase water: acetonitrile in the ratio 80:20 (Meghashri et al., 2010). The following standards were used to measure Ferulic acid 
$(321 \mathrm{~nm})$, Gallic acid $(272 \mathrm{~nm})$, Rutin $(257 \mathrm{~nm})$, Quercetin $(257 \mathrm{~nm})$, and Vanillic acid $(261 \mathrm{~nm})$ with $1 \mathrm{~mL} / \mathrm{min}$ flow rate.

\section{Molecular Docking}

In silico analyses provides molecular insights (Ranganatha et al., 2014; Satapathy et al., 2020) on the interaction of ligands (phyto-molecules) with that of the receptors (target enzymes). In the current study, two major classes of targets were analyzed (1). The enzymes regulating redox machinery and (2). Enzymes involved in calcium oxalate regulation. Henceforth, four major antioxidant enzymes namely Superoxide dismutase (PDB: 2V0A), Peroxidase (PDB: 1PRX), Catalase (PDB: 5GKN), and Glutathione S-Transferase (PDB: 1LJR) were retrieved from Protein Data Bank (PDB). This was backed up by metabolic enzymes Alanine-Glyoxylate aminotransferase (PDB: 1HOC), Oxalyl-Coa decarboxylase (PDB: 2JIB), D-glycerate dehydrogenase (PDB: 1GDH), and Lactate dehydrogenase (PDB: $5 Z \mathrm{JF}$ ) were considered respectively. Four major ligand molecules were docked on the catalytic site of the receptors based on the HPLC profiling i.e., Gallic acid (PubChem: 370), Vanillic acid (PubChem: 8468), Rutin (PubChem: 5280805), and Potassium Magnesium Citrate (PubChem: 10437763) among which the latter served as the standard drug which is currently used for treating kidney stones. Molegro Docking software package was used with visual docker and the results were analyzed considering the atomic contact energy (ACE) and gliding values (Rakesh et al., 2015, 2016; Satapathy et al., 2020).

\section{Statistical analysis}

All data were expressed as mean \pm standard deviation $(n=3)$. Results were determined using one-way analysis of variance (ANOVA), followed by Duncan's multiple range test using GraphPad Software, Inc (version 6.0, California, USA). The results were considered statistically significant if the $P<0.05$. The minimum dosage of extract that is necessary to produce $50 \%$ inhibition was known as the effective dose $\left(\mathrm{ED}_{50}\right)$, which is calculated using regression analysis.

\section{Results \& Discussion}

Phytofractions are extensively used as nutraceuticals in complementary and alternative medicine to boost health and to prevent stress, inflammation, and secondary lifestyle diseases. The current study investigates the interconnection of antioxidants and regulation of calcium oxalate which is a burgeoning area of research that is gaining increased 
attention due to the increased number of urolithiasis cases globally. We examined the ability of naturally occurring plant-derived aqueous fractions for their anti-stress and anti-urolithiatic efficacy in the prevention and treatment of the disease using in vitro and in silico platforms.

With the background of Indian traditional medicine (Ayurveda) and folklore, twenty priority botanicals with various other bioactivities were selected namely Aegle marmelos, Apium graveolens, Artocarpus heterophyllus, Azadirachta indica, Citrus limon, Citrus sinensis, Coriandrum sativum, Cucumis sativus, Kalanchoe pinnata, Lawsonia inermis, Mangifera indica, Manilkara zapota, Momordica charantia, Moringa oleifera, Musa paradisiaca, Phyllanthus emblica, Plectranthus amboinicus, Psidium guajava, Punica granatum and Ribes Uva-crispa (table 1) and their leaves component were screened for their antioxidant and anti-urolithiatic potency using aqueous hot extraction method. This extraction method was intentionally used with the purpose to formulate homemade decoctions with the motto of making food as medicine. The phyto-cocktails from all 20 extracts were subjected to qualitative phytochemical profiling for the presence of carbohydrates, glycosides, alkaloids, phenols, flavonoids, tannins, triterpenoids, steroids, saponin, and gums (supplementary table 1). Among them, most of the aqueous extract was found to be composed of the abovementioned phytochemical classes. However, glycosides and steroids were absent in most of the extracts indicating the non-dissolution of hydrophobic phyto-molecules. Most of the hydrophilic phyto-molecules (tight and loosely bound secondary metabolites) were extracted during the procedure. This observation implies an increased bioavailability of the phytococktail with enhanced bioabsorption within the system. All aqueous extracts were further subjected to the estimation of total phenolic content (TPC) to ensure the quantitative measurements (figure 1). Among the 20 leaves extracts P.granatum, M.oleifera, P.guajava, and C.sativum contented higher levels (nearing $2 \mathrm{mg} / \mathrm{mL}$ ) whereas, M.charantia and C.sativus exhibited the least (nearing $0.5 \mathrm{mg} / \mathrm{mL}$ ) phenolic content. The rest of the 14 extracts possessed (a range between 1 to $1.5 \mathrm{mg} / \mathrm{mL}$ ) of phenolics. For all dose-dependent studies, TPC was considered for quantitation.

Oxyradicals majorly reactive oxygen species (ROS) and reactive nitrogen species (RNS) are generated during metabolic insult and are the prime cause for biomolecular dysregulation, cellular damage, accounting for cell membrane disruption, mitochondrial dysbiosis, protein folding, inflammation leading to a high frequency of time-dependent diseases like early aging, cancer and neurodegenerative disorders which hampers general health maintenance. According to Vina and co-workers (2005), oxidants are the primordial 
cause for any disorders. Striking a proper equilibrium with antioxidant molecules will largely facilitate the chances of better survival. Hence a quest for exploring potent phyto-antioxidants is an urgent necessity to overcome lifestyle-related diseases (Garg et al., 2020). In the current study, all the 20 aqueous hot leaf extracts were subjected for their efficacy to quench free radical scavenging (figure 2) in a dose-dependent manner at $5 \mu \mathrm{g} / \mathrm{mL}, 15 \mu \mathrm{g} / \mathrm{mL}$, and $25 \mu \mathrm{g} / \mathrm{mL}$ of TPC respectively. DPPH (figure $2 \mathrm{~A}$ ), metal chelating (figure $2 \mathrm{~B}$ ), and reducing power (figure 2C) assays were employed. Ethylenediaminetetraacetic acid (EDTA) was used as a standard for metal chelating assay and gallic acid was used as the standard for the other two assays. In DPPH assay, A.indica, K.pinnata, P.granatum, and P.emblica were found to have better free radical scavenging activity. Whereas, A.graveolens, C.sativum, C.sativus, and P.amboinicus indicated the least activity among the 20 screened botanicals (figure 2A). However, M.zapota, M.charantia, and M.oleifera exhibited better metal chelating ability. Further, A.indica and C.sativus showed the least activity among the screened phytoextracts (figure 2B). The reducing power assay was well responded with C.limon, K.pinnata, L.inermis, M.indica, P.emblica, and P.granatum extracts and on the contrary, A.heterophyllus, C.sativus, M.charantia, P.amboinicus, and P.guajava exhibited the least activity (figure 2C). Similar results (Bidchol et al., 2011; Wong et al., 2014; Nedamani et al., 2015) have been well document by the previous researchers.

Besides, the antioxidant potency, the 20 selected botanicals with a concentration of $25 \mu \mathrm{g} / \mathrm{mL}$ were subjected to spectral studies, to assess their ability in inhibiting calcium oxalate crystal formation with cystone as the standard herbal drug (figure 3). The results exhibited that among the screened extracts C.sativum, K.pinnata, M.oleifera, and M.paradisiaca, were found to have evidence in inhibiting calcium oxalate crystal formation. Henceforth for all further studies, these five aqueous phytoextracts were considered. Further, the top five extracts were subjected to an in vitro experimental chicken egg membrane model to mimic the dissolution across the biological membrane (figure 4) of which K.pinnata exhibited $71 \%$ dissolution than other extracts in comparison to cystone standard $(86 \%)$. Hence for all the further experimentation leaves aqueous hot extract of K.pinnata was used and subjected to critical analyses.

Nucleation and aggregation are the two major phases during lithiasis. To assess the sequential effectiveness of K.pinnata, the extract was subjected in a dose-dependent manner at a range of concentrations $(5 \mu \mathrm{g} / \mathrm{mL}, 10 \mu \mathrm{g} / \mathrm{mL}, 15 \mu \mathrm{g} / \mathrm{mL}, 20 \mu \mathrm{g} / \mathrm{mL}$, and $25 \mu \mathrm{g} / \mathrm{mL})$ respectively with $25 \mu \mathrm{g} / \mathrm{mL}$ of cystone as standard drug formulation. The calcium oxalate 
curve was considered as untreated standard (supplementary figure 1) The nucleation assay was assessed at $1 \mathrm{~h}, 3 \mathrm{~h}$, and $24 \mathrm{~h}$ after incubation (figure 5A). The results provided sufficient evidence that after $24 \mathrm{~h}$ of incubation a promising inhibition (70\%) of calcium oxalate was observed with K.pinnata extract compared to cystone (76\%). Further, aggregation assessment was also performed to have a microscopic birds' eye view on the crystal dissolution (figure 5B). Thus, K.pinnata extract was found to be a potent anti-crystallization contributor. This could be probably due to higher concentrations of flavonoids, saponins, and gums (VanDooren et al., 2016) which has a shred of qualitative evidence with phytochemical profiling (supplementary table 1).

Further, to evaluate the toxicity of the K.pinnata extract RBC (figure 6: Panel A) and DNA (figure 6: Panel B) protection assay were performed. The K.pinnata phyto-cocktail exhibited potential hampering of the induced oxidant partially at $5 \mu \mathrm{g} / \mathrm{mL}$ and completely at $25 \mu \mathrm{g} / \mathrm{mL}$ in comparison to gallic acid (pure drug) and cystone (formulation) as standard drug. Similar kind of studies has been evident with Beulah et al., (2015) and Meghashri et al., (2010) respectively. HPLC profiling was performed (figure 7) on aqueous K.pinnata leaves extract. The sample was found to contain gallic acid at $272 \mathrm{~nm}$, rutin at $257 \mathrm{~nm}$, and vanillic acid at $261 \mathrm{~nm}$ whereas, ferulic acid and quercetin were present in minor quantities. The chromatogram for standards has been provided in supplementary figure 2 .

Inside a cell, biomarkers such as antioxidant, inflammatory, and calcium oxalate regulating metabolic enzymes play a pivitol role in maintaining cellular homeostasis during lithiasis. Hence an attempt was made to investigate these two classes of enzymes namely catalase (CAT), superoxide dismutase (SOD), peroxidase (PER), glutathione S-transferase (GST), contributing towards redox machinery and stress respectively. Besides, metabolic enzymes such as alanine-glyoxlate aminotransferase, oxalyl-coA decarboxylase, D-glycerate dehydrogenase, and lactate dehydrogenase $(\mathrm{LDH})$ regulate a crucial role in stone formation, and inflammation was considered for the study. Three major ligands namely, gallic acid, rutin, and vanillic acid were considered with potassium-magnesium citrate as the standardcurrently used drug for urolithiasis. Structure-activity relationship (SAR) studies were performed for antioxidant (figure 8) and calcium oxalate regulating enzymes (figure 9) with the best-docked pose. Further, the data have been tabulated in table 2 and table 3 respectively indicating the specific amino acid which comprises the active site for the target and ligand. Among the docked ligands rutin (molar mass: $610.517 \mathrm{~g} / \mathrm{mol}$ ) was found to be active and best docked on both the classes of the target enzymes than compared to the available drug 
currently used by clinicians to treat uro/nephrolithiasis. Previous studies on rutin as a potent antioxidant and anti-urolithiatic agent have been well document by Enogieru, et al., (2018) and Ghodasara et al., (2010) respectively. Further, Radwan et al (2021) and Santos et al., (2021) have explored the possible role of the K. pinnata attributes in hemostasis and oxytocin signaling pathways respectively.

Finally, to summarize, the current study has made an exciting observation that K.pinnata aqueous leaves extract can completely suppress the clinical disease in an experimental in vitro model of urolithiasis. However, further studies at a molecular level are needed to test the central hypothesis that $K$. pinnata has a profound effect on pro- and antiinflammatory responses regulating transcriptional activity which may lead to the amelioration of the disease. Newer in silico algorithms have to be generated which can target gene prediction and pathways that are dysregulated during urolithiasis. In conclusion, these studies should provide novel insights into the basic mechanisms through which phyto-cocktails exhibits anti-lithiatic properties so that it can be used against a wide range of lifestyle diseases leading to better health and wellbeing.

Conflict of Interest: All authors declare no conflict of interest.

\section{Acknowledgments:}

Ms. Aishwarya Tripurasundari Devi would like to thank the Indian Council of Medical Research (ICMR) for the award of Senior Research Fellow (SRF) Award Letter Number File no.5/3/8/55/ITR-F/2018-ITR dated 11.6.2018. The authors thank, Dr. Trevani, Herbarium Section, Department of Studies in Botany, University of Mysore, for identification of the screened botanicals. All authors thank the Hon'ble Vice-Chancellor, JSS Science and Technology University, Principal, SJCE, Mysore for his encouragement, and JSS research foundation for their constant inspiration. All the authors are thankful to Dr. Shaukath Ara Khanum, Department of Chemistry, Yuvaraja College, and Dr. Shubha Gopal, Department of Studies in Microbiology, University of Mysore, Mysore for the long-term collaboration and guidance in understanding the biology of phytochemical molecules. Further, we extend our gratitude towards the management and office bearers of Dayananda Sagar University (DSU), Bengaluru, Karnataka, India, for constant inspiration, motivation, and encouragement to pursue scientific research. Special thanks to Prof. Sunil S. More, Dean, School of Basic and Applied Sciences, DSU for all approval and permissions during the execution of this research work. 


\section{References:}

Janardhan B, Shrikanth VM, More VS, Melappa G, Zameer F, More SS. Bungarus caeruleus venom neutralization activity of Azima tetracantha Lam. Extract. Heliyon. 2019 Jul 29;5(7):e02163.

Vineetha MS, Bhavya J, Veena SM, Mirajkar KK, Muddapur U, Ananthraju KS, Zameer F, More SS. In vitro and in vivo inhibitory effects of Tabernaemontana alternifolia against Naja naja venom. Saudi Pharm J. 2020 Jun;28(6):692-697.

Bhavya J, Vineetha M. Shrikanth, Veena SM, Govindappa Melappa, Ananthraju KS, Zameer $\mathrm{F}$ and More SS. Inhibitory Effect of Carissa spinarum Linn methanolic leaf extract against Vipera russelli. Venoms and Toxins (2021) 1: 85.

Kunnel SG, Subramanya S, Satapathy P, Sahoo I, Zameer F. Acrylamide Induced Toxicity and the Propensity of Phytochemicals in Amelioration: A Review. Cent Nerv Syst Agents Med Chem. 2019;19(2):100-113.

Satapathy P, Prakash JK, Gowda VC, More SS, K M, Chandramohan V, Zameer F. Targeting Imd pathway receptor in Drosophila melanogaster and repurposing of phyto-inhibitors: structural modulation and molecular dynamics. J Biomol Struct Dyn. 2020 Oct 14:1-12.

Putta S, Yarla NS, Kilari EK, Surekha C, Aliev G, Divakara MB, Santosh MS, Ramu R, Zameer F, Mn NP, Chintala R, Rao PV, Shiralgi Y, Dhananjaya BL. Therapeutic Potentials of Triterpenes in Diabetes and its Associated Complications. Curr Top Med Chem. 2016;16(23):2532-42.

Prasad A, Devi AT, Prasad MNN, Zameer F, Shruthi G, Shivamallu C. Phyto anti-biofilm elicitors as potential inhibitors of Helicobacter pylori. 3 Biotech. 2019 Feb;9(2):53.

Rakesh KS, Jagadish S, Swaroop TR, Mohan CD, Ashwini N, Harsha KB, Zameer F, Girish KS, Rangappa KS. Anti-Cancer Activity of 2,4-Disubstituted Thiophene Derivatives: Dual Inhibitors of Lipoxygenase and Cyclooxygenase. Med Chem. 2015;11(5):462-72.

Zameer F, Rukmangada MS, Chauhan JB, Khanum SA, Kumar P, Devi AT, Mn NP, Bl D. Evaluation of adhesive and anti-adhesive properties of Pseudomonas aeruginosa biofilms and their inhibition by herbal plants. Iran J Microbiol. 2016 Apr;8(2):108-19.

Rakesh KS, Jagadish S, Balaji KS, Zameer F, Swaroop TR, Mohan CD, Jayarama S, Rangappa KS. 3,5-Disubstituted Isoxazole Derivatives: Potential Inhibitors of Inflammation and Cancer. Inflammation. 2016 Feb;39(1):269-280.

Grases, F., Sanchis, P., Isern, B., Perelló, J., \& Costa-Bauzá, A. (2007). Uric acid as inducer of calcium oxalate crystal development. Scand J Urol Nephrol. 41, 1, 26-31.

Tatapudi VS, Modersitzki F, Marineci S, Josephson MA, Goldfarb DS. Medical evaluation of living kidney donors with nephrolithiasis: a survey of practices in the United States. Clin Exp Nephrol. 2020 Mar;24(3):259-267. 
Han, H., Segal, A. M., Seifter, J. L. \& Dwyer, J. T. (2015). Nutritional management of kidney stones (nephrolithiasis). Clin Nutr Res. 4, 3, 137-152.

Paliouras, C., Tsampikaki, E., Alivanis, P. \& Aperis, G. (2012). Pathophysiology of nephrolithiasis. Nephrology Research \& Reviews. 4, 2, 58-65.

Moe, O. W. (2006). Kidney stones: pathophysiology and medical management. Lancet. 367, 9507, 333-344.

Evan AP, Worcester EM, Coe FL, Williams J Jr, Lingeman JE. Mechanisms of human kidney stone formation. Urolithiasis. 2015 Jan;43 Suppl 1(0 1):19-32.

Phatak RS and Hendre AS. In-vitro anti-urolithiatic activity of Kalanchoe pinnata extract. International Journal of Pharmacognosy and Phytochemical Research 2015; 7(2); 275-279.

Pynam H, Dharmesh SM. Antioxidant and anti-inflammatory properties of marmelosin from Bael (Aegle marmelos L.); Inhibition of TNF- $\alpha$ mediated inflammatory/tumor markers. Biomed Pharmacother. 2018 Oct;106:98-108.

Chonpathompikunlert P, Boonruamkaew P, Sukketsiri W, Hutamekalin P, Sroyraya M. The antioxidant and neurochemical activity of Apium graveolens L. and its ameliorative effect on MPTP-induced Parkinson-like symptoms in mice. BMC Complement Altern Med. 2018 Mar 20;18(1):103.

Ranasinghe RASN, Maduwanthi SDT, Marapana RAUJ. Nutritional and Health Benefits of Jackfruit (Artocarpus heterophyllus Lam.): A Review. Int J Food Sci. 2019 Jan 6;2019:4327183.

Saleem S, Muhammad G, Hussain MA, Bukhari SNA. A comprehensive review of phytochemical profile, bioactives for pharmaceuticals, and pharmacological attributes of Azadirachta indica. Phytother Res. 2018 Jul;32(7):1241-1272.

Prabhu VV, Sathyamurthy D, Ramasamy A, Das S, Anuradha M, Pachiappan S. Evaluation of protective effects of diosmin (a citrus flavonoid) in chemical-induced urolithiasis in experimental rats. Pharm Biol. 2016 Sep;54(9):1513-21.

Ungjaroenwathana W, Chiramongkolsiri T, Dissayabutra T, Boonla C, Prapunwattana P, Tungsanga K, Tosukhowong $\mathrm{P}$. Lime powder regimen supplement alleviates urinary metabolic abnormalities in urolithiasis patients. Nephrology (Carlton). 2019 Aug;24(8):791797.

Laribi B, Kouki KM, Hamdi M, Bettaieb T. Coriander (Coriandrum sativum L.) andits bioactive constituents. Fitoterapia. 2015 Jun;103:9-26.

Trejo-Moreno C, Méndez-Martínez M, Zamilpa A, Jiménez-Ferrer E, Perez-GarciaMD, Medina-Campos ON, Pedraza-Chaverri J, Santana MA, Esquivel-Guadarrama FR, Castillo A, Cervantes-Torres J, Fragoso G, Rosas-Salgado G. Cucumis sativus Aqueous Fraction Inhibits 
Angiotensin II-Induced Inflammation and Oxidative Stress In Vitro. Nutrients. 2018 Feb 28;10(3):276.

Sohgaura AK, Bigoniya P, Shrivastava B. In Vitro Antilithiatic Potential of Kalanchoe pinnata, Emblica officinalis, Bambusa nutans, and Cynodon dactylon. J Pharm Bioallied Sci. 2018 Apr-Jun;10(2):83-89.

Ferreira RT, Coutinho MA, Malvar Ddo C, Costa EA, Florentino IF, Costa SS, Vanderlinde FA. Mechanisms Underlying the Antinociceptive, Antiedematogenic, and Anti-Inflammatory Activity of the Main Flavonoid from Kalanchoe pinnata. Evid Based Complement Alternat Med. 2014;2014:429256.

Elansary HO, Szopa A, Kubica P, Ekiert H, A Al-Mana F, Al-Yafrsi MA. Antioxidant and Biological Activities of Acacia saligna and Lawsonia inermis Natural Populations. Plants (Basel). 2020 Jul 17;9(7):908.

Batool N, Ilyas N, Shabir S, Saeed M, Mazhar R. Mini-Review- A mini-review of therapeutic potential of Mangifera indica L. Pak J Pharm Sci. 2018 Jul;31(4):1441-1448.

Sharma B, Singh I, Bajar S, Gupta S, Gautam H, Kumar P. Biogenic Silver Nanoparticles: Evaluation of Their Biological and Catalytic Potential. Indian J Microbiol. 2020 Dec;60(4):468-474.

Jia S, Shen M, Zhang F, Xie J. Recent Advances in Momordica charantia: Functional Components and Biological Activities. Int J Mol Sci. 2017 Nov 28;18(12):2555.

Karadi RV, Gadge NB, Alagawadi KR, Savadi RV. Effect of Moringa oleifera Lam. rootwood on ethylene glycol induced urolithiasis in rats. J Ethnopharmacol. 2006 Apr 21;105(12):306-11.

Bhattacharya A, Tiwari P, Sahu PK, Kumar S. A Review of the Phytochemical and Pharmacological Characteristics of Moringa oleifera. J Pharm Bioallied Sci. 2018 OctDec;10(4):181-191.

Panigrahi PN, Dey S, Sahoo M, Dan A. Antiurolithiatic and antioxidant efficacy of Musa paradisiaca pseudostem on ethylene glycol-induced nephrolithiasis in rat. Indian $\mathrm{J}$ Pharmacol. 2017 Jan-Feb;49(1):77-83.

Krishnaveni M, Mirunalini S. Therapeutic potential of Phyllanthus emblica (amla): the ayurvedic wonder. J Basic Clin Physiol Pharmacol. 2010;21(1):93-105.

Li W, Zhang X, Chen R, Li Y, Miao J, Liu G, Lan Y, Chen Y, Cao Y. HPLC fingerprint analysis of Phyllanthus emblica ethanol extract and their antioxidant and anti-inflammatory properties. J Ethnopharmacol. 2020 May 23;254:112740.

Arumugam G, Swamy MK, Sinniah UR. Plectranthus amboinicus (Lour.) Spreng: Botanical, Phytochemical, Pharmacological and Nutritional Significance. Molecules. 2016 Mar 30;21(4):369. 
Agarwal K, Varma R. Ethnobotanical study of antilithic plants of Bhopal district. J Ethnopharmacol. 2015 Nov 4;174:17-24.

Vasconcelos AG, Amorim ADGN, Dos Santos RC, Souza JMT, de Souza LKM, Araújo TSL, Nicolau LAD, de Lima Carvalho L, de Aquino PEA, da Silva Martins C, Ropke CD, Soares PMG, Kuckelhaus SAS, Medeiros JR, Leite JRSA. Lycopene rich extract from red guava (Psidium guajava L.) displays anti-inflammatory and antioxidant profile by reducing suggestive hallmarks of acute inflammatory response in mice. Food Res Int. 2017 Sep;99(Pt 2):959-968.

Rathod NR, Biswas D, Chitme HR, Ratna S, Muchandi IS, Chandra R. Anti- urolithiatic effects of Punica granatum in male rats. J Ethnopharmacol. 2012 Mar 27;140(2):234-8.

Saeed M, Naveed M, BiBi J, Kamboh AA, Arain MA, Shah QA, Alagawany M, El-Hack MEA, Abdel-Latif MA, Yatoo MI, Tiwari R, Chakraborty S, Dhama K. The Promising Pharmacological Effects and Therapeutic/Medicinal Applications of Punica Granatum L. (Pomegranate) as a Functional Food in Humans and Animals. Recent Pat Inflamm Allergy Drug Discov. 2018;12(1):24-38.

Laczkó-Zöld E, Komlósi A, Ülkei T, Fogarasi E, Croitoru M, Fülöp I, Domokos E, Ştefănescu R, Varga E. Extractability of polyphenols from black currant, red currant and gooseberry and their antioxidant activity. Acta Biol Hung. 2018 Jun;69(2):156-169.

Pankaj S, S. Aishwarya, M. Rashmi Shetty, N. Akshaya Simha, G. Dhanapal, R. Aishwarya Shree, Antara Biswas, K. Kounaina, Anirudh G. Patil, M.G. Avinash, Aishwarya T. Devi, Shubha Gopal, M.N. Nagendra Prasad, S.M. Veena, S.P. Hudeda, K. Muthuchelian, Sunil S. More, Govindappa Melappa and Farhan Zameer. Phyto-Nano-Antimicrobials: Synthesis, Characterization, Discovery, and Advances. Frontiers in Anti-Infective Drug Discovery; Bentham Science International, 2020, 8 (36), 196-231.

Khan K, S Aishwarya, Pankaj Satapathy, Veena SM, Govindappa Melappa, Farhan Zameer, Shivaprasad Hudeda and Sunil S. More. Exploration of Dill Seeds (Anethum Graveolens): An Ayurpharmacomic Approach. Science of Spices and Culinary Herbs - Latest Laboratory, Preclinical, and Clinical Studies. Bentham Science International. 2020, 37(2), 116-152.

Aishwarya S., Kounaina Khan, Anirudh Gururaj Patil, Pankaj Satapathy, Aishwarya T. Devi, M.G. Avinash, S.M. Veena, Shubha Gopal, M.N. Nagendra, K. Muthucheliyan, Shivaprasad Hudeda, Farhan Zameer and Sunil S. More. Nutraceutical Attributes of Tamarindus indica L. - Devils' Tree with Sour Date. Science of Spices and Culinary Herbs - Latest Laboratory, Pre-clinical, and Clinical Studies. Bentham Science International. 2020, 33(3), 33-65.

Gulcin, İ. Antioxidants and antioxidant methods: an updated overview (2020). Arch Toxicol 94, 651-715.

Gopal S, Srinivas V, Zameer F, Kreft J. Prediction of proteins putatively involved in the thiol: disulfide redox metabolism of a bacterium (Listeria): the CXXC motif as query sequence. In Silico Biol. 2009;9(5-6):407-14. 
Ramu R, Shirahatti PS, Anilakumar KR, Nayakavadi S, Zameer F, Dhananjaya BL, Nagendra Prasad MN. Assessment of Nutritional Quality and Global Antioxidant Response of Banana (Musa sp. Nanjangud Rasa Bale) Pseudostem and Flower. Pharmacognosy Res. 2017 Dec;9(Suppl 1): S74-S83.

Madhusudhan M, Zameer F, Naidu A, M N NP, Dhananjaya BL, Hegdekatte R. Evaluating the inhibitory potential of Withania somnifera on platelet aggregation and inflammation enzymes: An in vitro and in silico study. Pharm Biol. 2016 Sep;54(9):1936-41.

Meghashri S, JB Chauhan, AA Syed, F Zameer. Effect of Ocimum tenuiflorum Leaf Extract against Infective Endocarditis. International Journal of Phytomedicine. 2011 (3), 470-474

Meghashri S, Kumar VH, Gopal S. Antioxidant properties of a novel flavonoid from leaves of Leucas aspera. Food Chemistry. 2010, 122(1): 105-110.

Nedamani RE, Sadeghi Mahoonak A, Ghorbani M, Kashaninejad M. Evaluation of antioxidant interactions in combined extracts of green tea (Camellia sinensis), rosemary (Rosmarinus officinalis) and oak fruit (Quercus branti). J Food Sci Technol. 2015 Jul;52(7):4565-71.

Shameh S, Hosseini B, Alirezalu A, Maleki R. Phytochemical Composition and Antioxidant Activity of Petals of Six Rosa Species from Iran. J AOAC Int. 2018 Nov 1;101(6):17881793.

Monika, J., Bhandari, A., Bhandari, A., Patel, P (2012). Isolation, characterization and in vitro antiurolithiatic activity of Cerpegin alkaloid from Ceropegia bulbosa var. Lushii root. International Journal of Drug Development and Research 4(4): 154-160.

Saha, S. and R. J. Verma (2013). Inhibition of calcium oxalate crystallisation in vitro by an extract of Bergenia ciliata. Arab journal of urology 11(2): 187-192.

Beulah KC, Aishwarya T Devi, Waseem K, Hedgekatte R, Nagendra Prasad MN, Dhananjaya BL, Farhan Zameer (2015). Screening for Bioactives from Indian Medicinal Herbs - A Simplistic Approach for antioxidant metabolites. International Journal of Pharmacy and Pharmaceutical Sciences 7(1), 195-198.

Ranganatha VL, Begum AB, Naveen P, Zameer F, Hegdekatte R, Khanum SA. Synthesis, xanthine oxidase inhibition, and antioxidant screening of benzophenone tagged thiazolidinone analogs. Arch Pharm (Weinheim). 2014 Aug;347(8):589-98.

Viña J, Borrás C, Gambini J, Sastre J, Pallardó FV. Why females live longer than males? Importance of the upregulation of longevity-associated genes by oestrogenic compounds. FEBS Lett. 2005 May 9;579(12):2541-5.

Garg SS, Gupta J, Sharma S, Sahu D. An insight into the therapeutic applications of coumarin compounds and their mechanisms of action. Eur J Pharm Sci. 2020 Sep 1;152:105424. 
Wong FC, Yong AL, Ting EP, Khoo SC, Ong HC, Chai TT. Antioxidant, Metal Chelating, Anti-glucosidase Activities and Phytochemical Analysis of Selected Tropical Medicinal Plants. Iran J Pharm Res. 2014;13(4):1409-15.

Bidchol, A. M., Wilfred A, Abhijna P, Harish R (2011). Free radical scavenging activity of aqueous and ethanolic extract of Brassica oleracea L. var. italica. Food and bioprocess technology 4(7): 1137-1143.

Van Dooren I, Foubert K, Bijttebier S, Theunis M, Velichkova S, Claeys M, Pieters L, Exarchou V, Apers S. Saponins and Flavonoids from an Infusion of Herniaria hirsuta. Planta Med. 2016 Dec;82(18):1576-1583.

Enogieru AB, Haylett W, Hiss DC, Bardien S, Ekpo OE. Rutin as a Potent Antioxidant: Implications for Neurodegenerative Disorders. Oxid Med Cell Longev. 2018 Jun 27;2018:6241017.

Ghodasara J, Pawar A, Deshmukh C, Kuchekar B. Inhibitory effect of rutin and curcumin on experimentally-induced calcium oxalate urolithiasis in rats. Pharmacognosy Res. 2010 Nov;2(6):388-92.

Radwan PJ, Janus L, Piatkowski M, Sierakowska A, Galek T, Szajna E, Bogdal D, Tupaj M. Fungal Chitosan-Derived biomaterials modified with Kalanchoe pinnata as potential hemostatic agents-development and characterization. Polymers (Basel). 2021 Apr $15 ; 13(8): 1300$.

Santos S, Zurfluh L, Mennet M, Potterat O, von Mandach U, Hamburger M, Simões-Wust AP. Bryophyllum pinnatum compounds inhibit oxytocin-induced signaling pathways in human myometrial cells. Front Pharmacol. 2021 Feb 18;12:632986. 


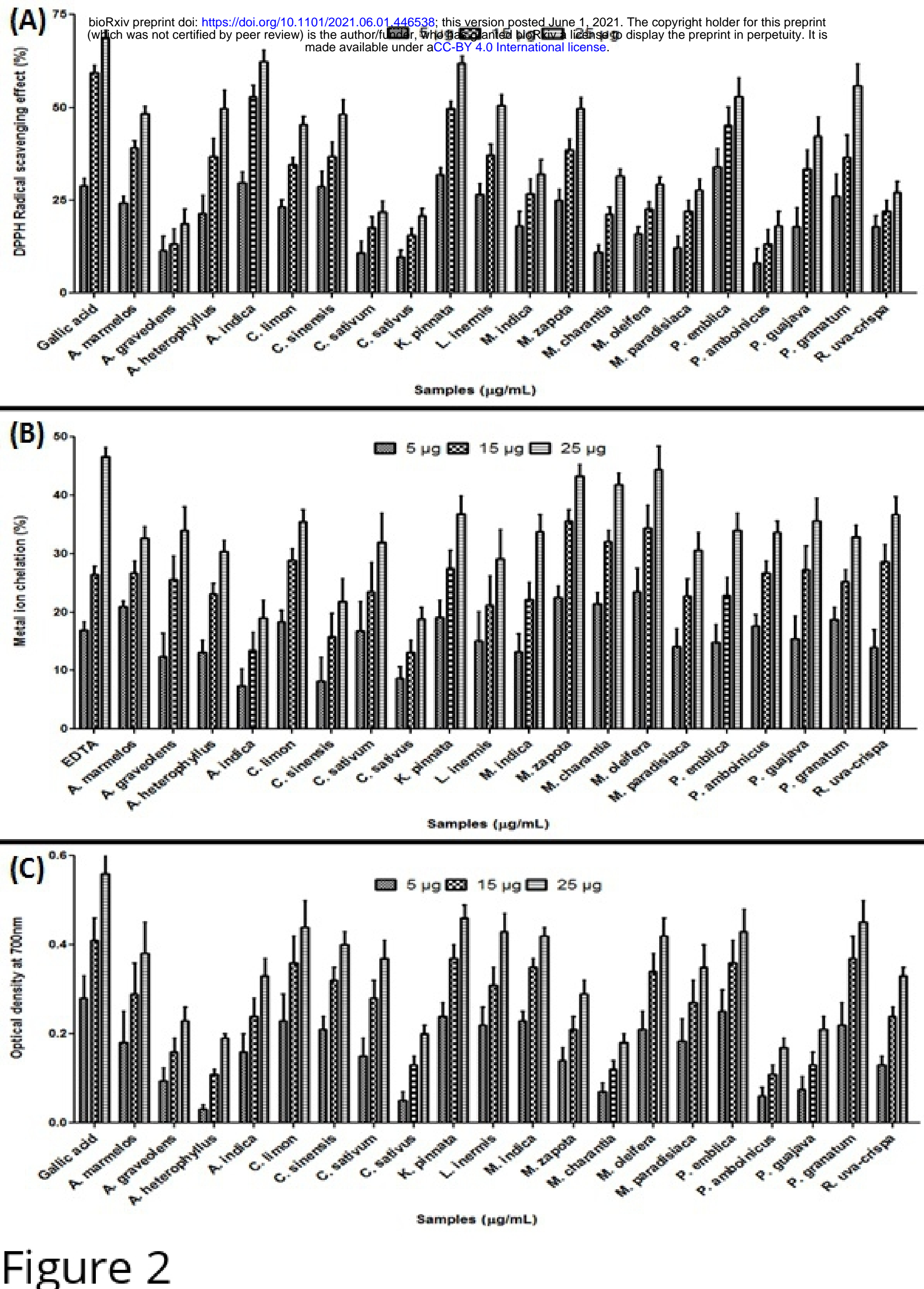




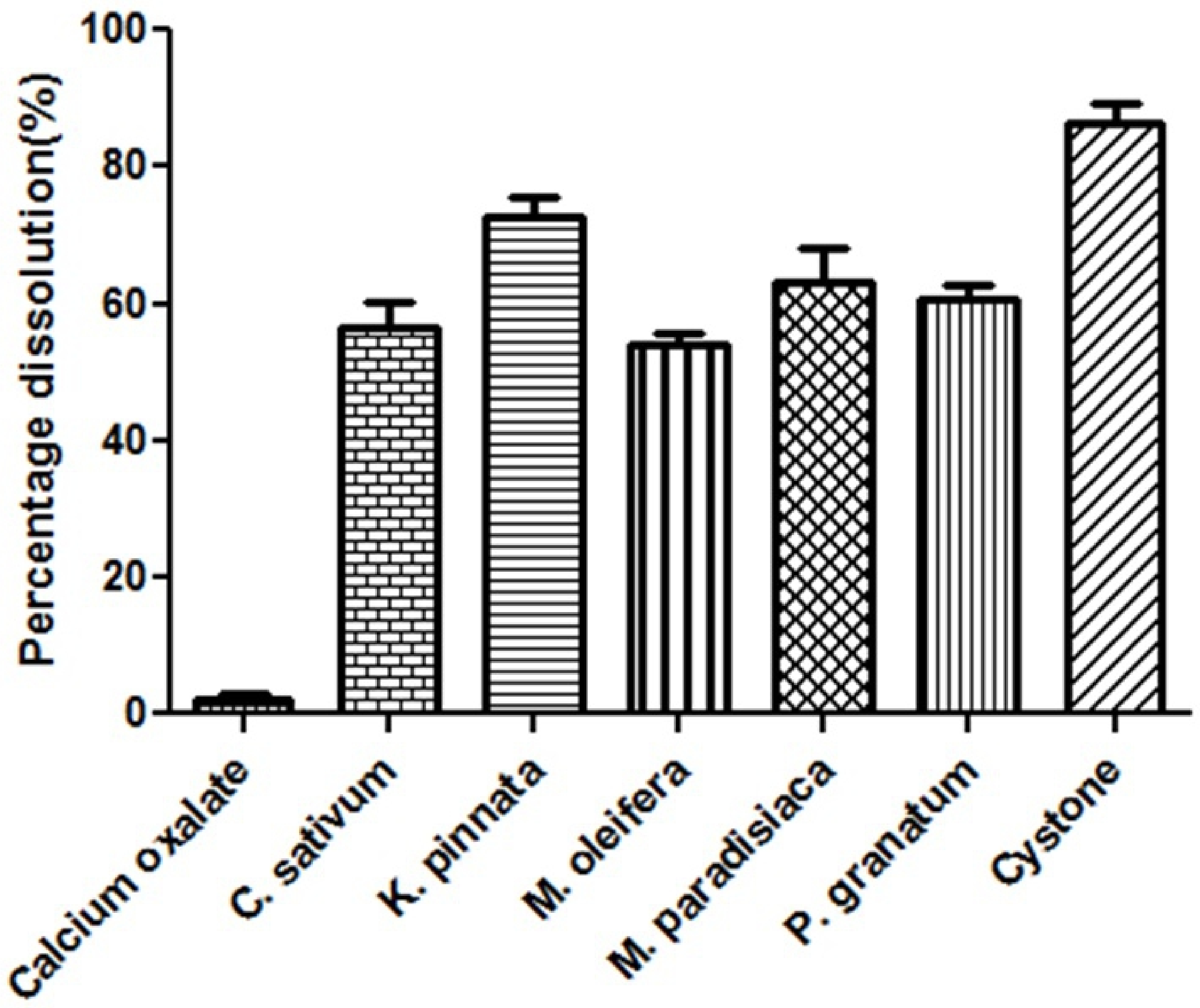

Figure 4 


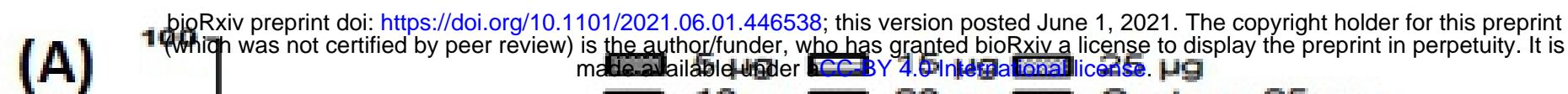

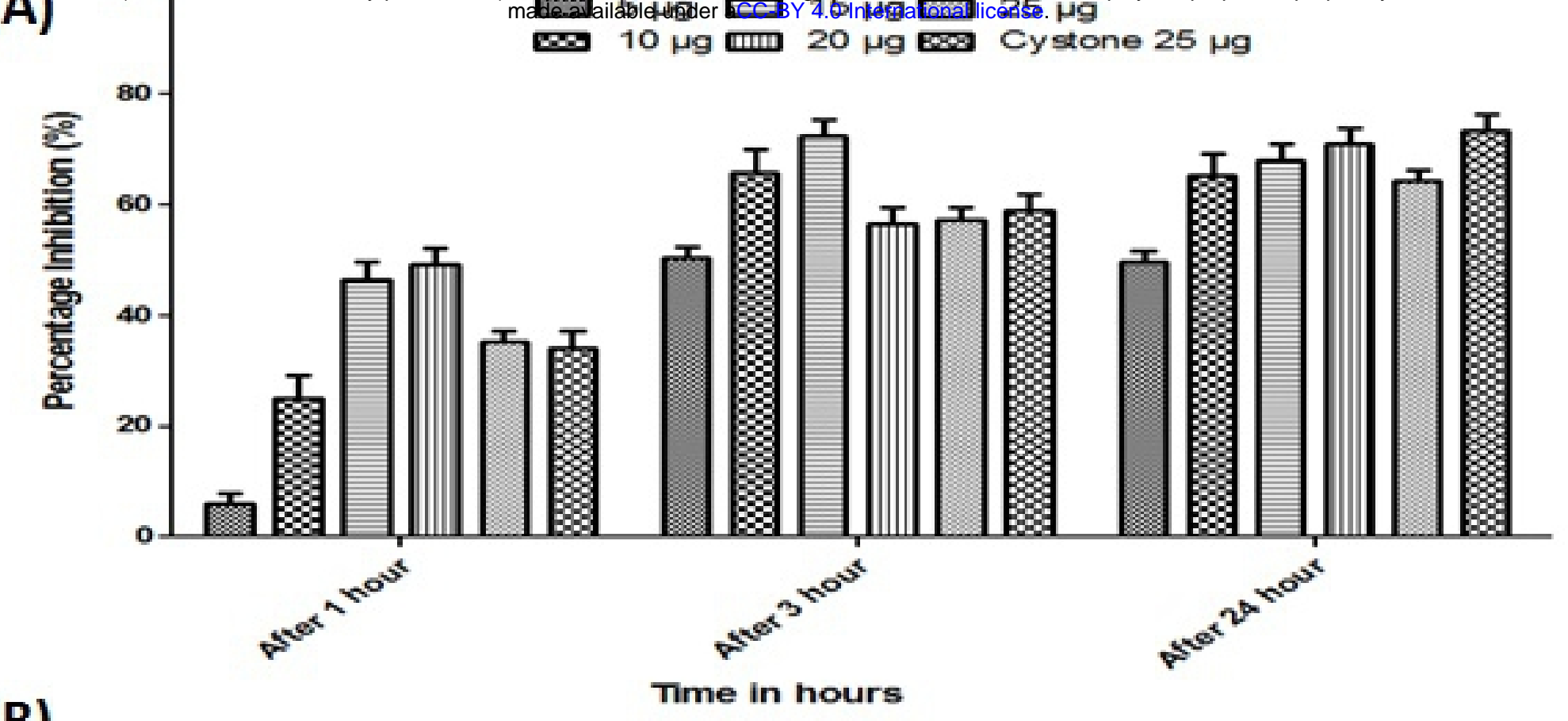

(B)

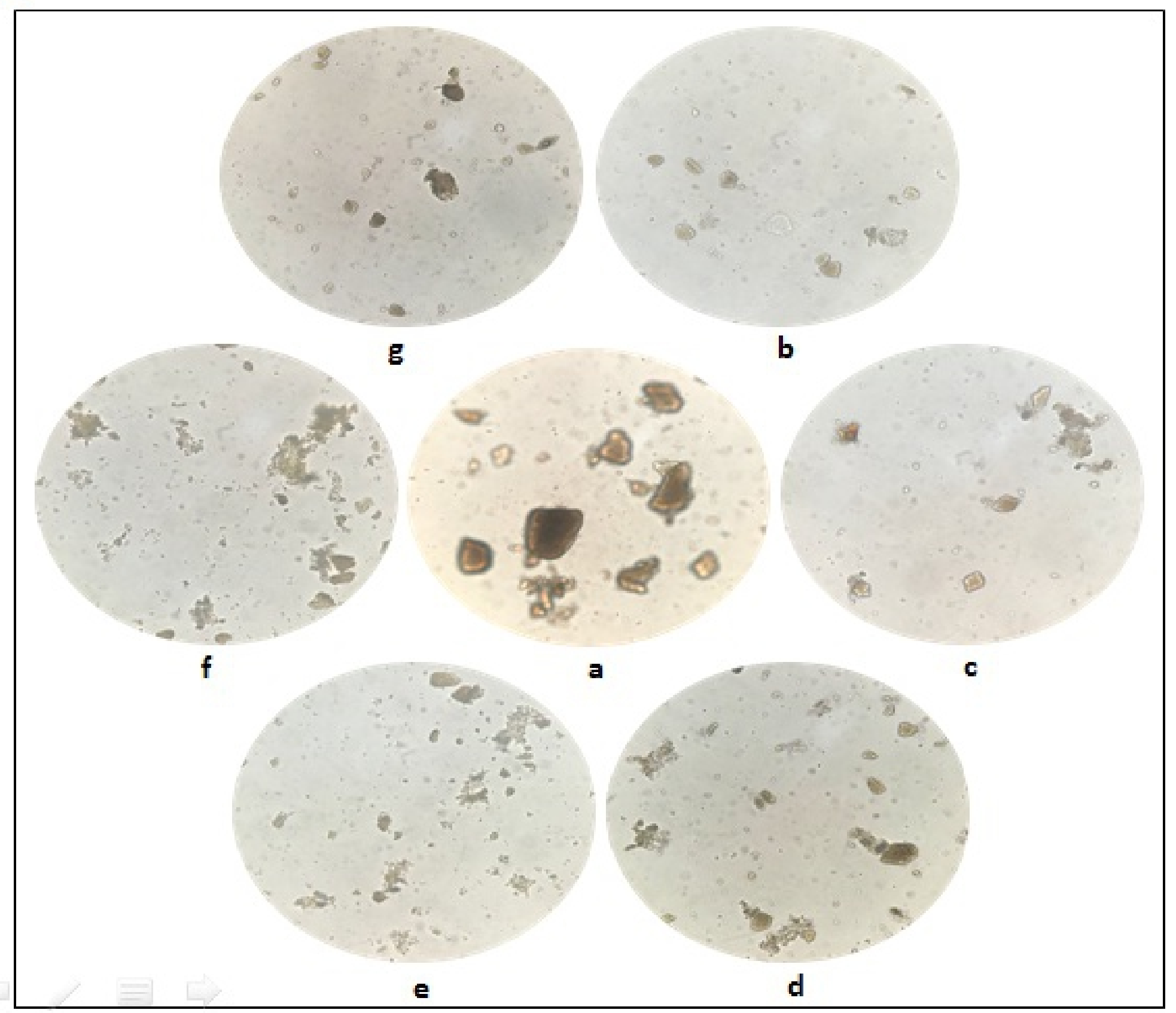

Figure 5 
Panel A

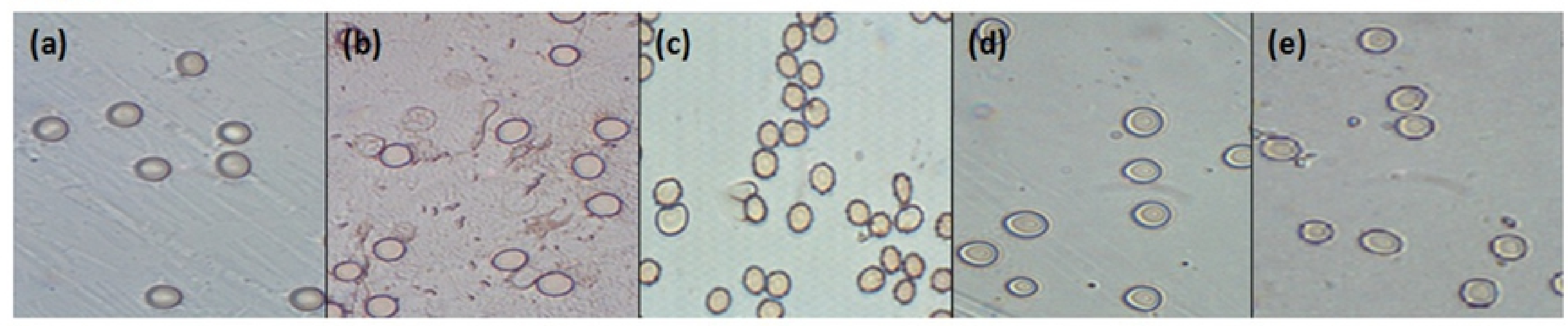

Panel B

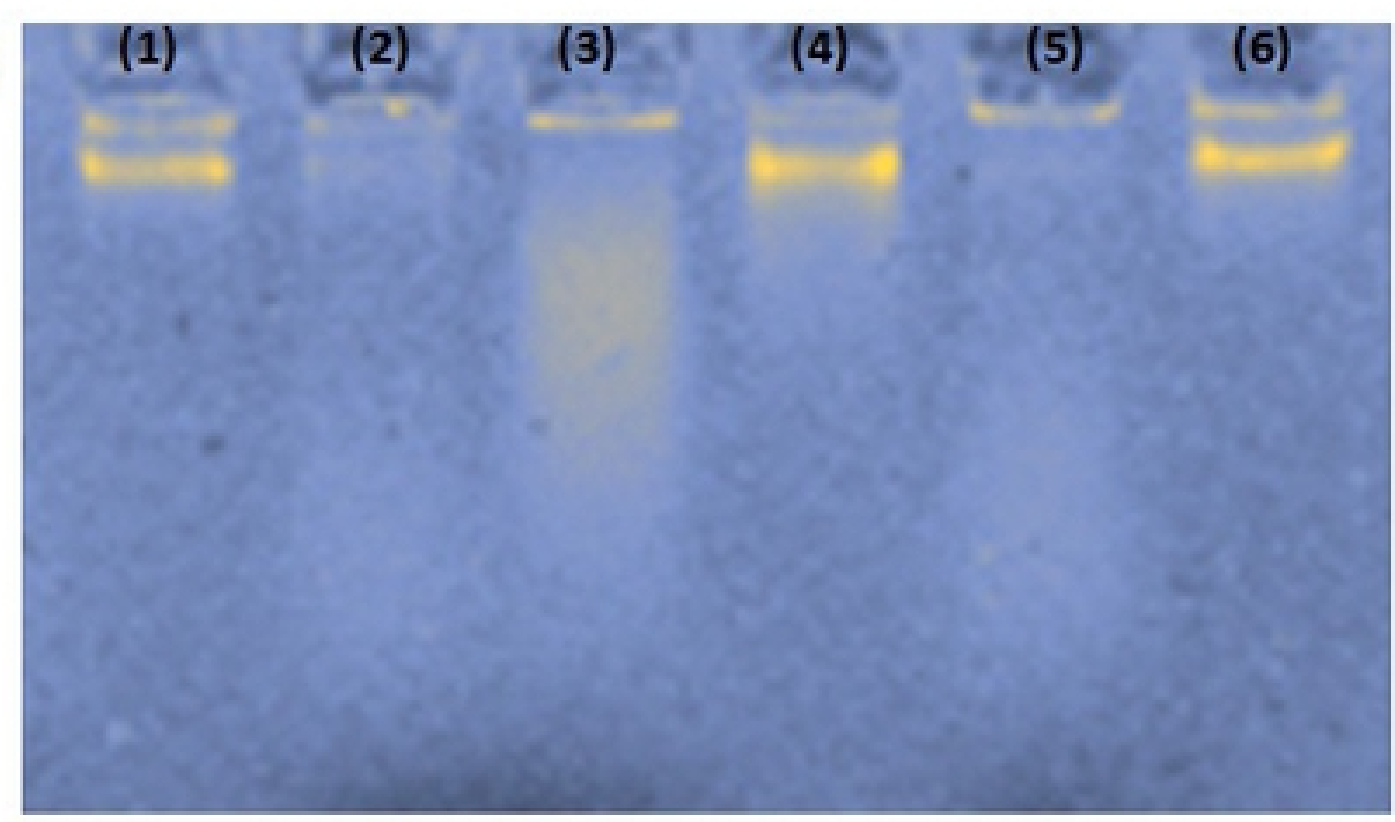

Figure 7 


\begin{tabular}{|c|c|c|c|c|c|}
\hline $\begin{array}{l}\text { Sl. } \\
\text { No }\end{array}$ & $\begin{array}{l}\text { BOTANICAL } \\
\text { NAME }\end{array}$ & $\begin{array}{l}\text { COMMON } \\
\text { NAME }\end{array}$ & FAMILY & BIOLOGICAL ACTIVITY & REFERENCES \\
\hline 1 & Aegle marmelos & Bael & Rutaceae & Antioxidant and anti-inflammatory properties & $\begin{array}{l}\text { Pynam \& Dharmesh } \\
\text { (2018) }\end{array}$ \\
\hline 2 & $\begin{array}{l}\text { Apium } \\
\text { graveolens }\end{array}$ & Celery & Apiaceae & $\begin{array}{l}\text { Antioxidant, neurochemical activity and also used in treatments for } \\
\text { hypertension, gout, and diabetes }\end{array}$ & $\begin{array}{l}\text { Chonpathompikunlert et } \\
\text { al., (2018) }\end{array}$ \\
\hline 3 & $\begin{array}{l}\text { Artocarpus } \\
\text { heterophyllus }\end{array}$ & Jackfruit & Moraceae & $\begin{array}{l}\text { Anticarcinogenic, antimicrobial, antifungal, anti-inflammatory, } \\
\text { wound healing, and hypoglycemic effects }\end{array}$ & Ranasinghe et al., (2019) \\
\hline 4 & $\begin{array}{l}\text { Azadirachta } \\
\text { indica }\end{array}$ & Neem & Meliaceae & $\begin{array}{l}\text { Hypolipidemic, antifertility, microbicidal, antidiabetic, anti- } \\
\text { inflammatory, hepatoprotective, antipyretic, hypoglycemic, } \\
\text { insecticidal, nematicidal, antiulcer, antioxidant, neuroprotective, } \\
\text { cardioprotective, and antileishmaniasis properties. }\end{array}$ & Saleem et al., (2018) \\
\hline 5 & Citrus limon & Lemon & Rutaceae & Antiurolithiatic activity & Prabhu et al., (2016) \\
\hline 6 & Citrus sinensis & Orange & Rutaceae & Antioxidant, Antiurolithiatic activity & $\begin{array}{l}\text { Ungjaroenwathana et al., } \\
\text { (2019) }\end{array}$ \\
\hline 7 & $\begin{array}{l}\text { Coriandrum } \\
\text { sathum }\end{array}$ & Coriander & Apiaceae & $\begin{array}{l}\text { Antimicrobial, antioxidant, hypoglycemic, hypolipidemic, } \\
\text { anxiolytic, analgesic, anti-inflammatory, anti-convulsant and } \\
\text { anticancer activities }\end{array}$ & Laribi et al., (2015) \\
\hline 8 & $\begin{array}{l}\text { Cucumis sativus } \\
\text { Rxiv preprint doi: https://c } \\
\text { ich was not certified by }\end{array}$ & $\begin{array}{l}\text { Cucumber } \\
\text { oi.org/10.1101/2021.06 } \\
\text { eer review) is the autho }\end{array}$ & $\begin{array}{l}\text { Cucurbitaceae } \\
\text { \$.01.446538; this version po\$t } \\
\text { or/funder, who has granted blo }\end{array}$ & $\begin{array}{l}\text { Anti-inflammatory, antioxidant activity } \\
\text { ted June } 1,2021 \text {. The copyright holder for this preprint } \\
\text { loRxiv a license to display the preprint in perpetwity lt is }\end{array}$ & $\begin{array}{l}\text { Trejo-Moreno et al., } \\
\text { (2018) }\end{array}$ \\
\hline 9 & $\begin{array}{l}\text { Kalanchoe } \\
\text { pinnata }\end{array}$ & Life plangade availa & blewnderialegeralet. 0 Intern & 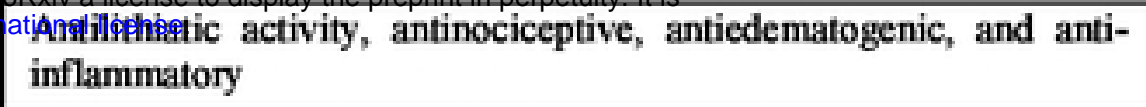 & $\begin{array}{l}\text { Sohgaura et al., (2018) } \\
\text { Ferreira et al., (2014) }\end{array}$ \\
\hline 10 & $\begin{array}{l}\text { Lawsonia } \\
\text { inermis }\end{array}$ & Henna & Lythraceae & Antibacterial, antifungal, antioxidant, antiproliferative, cytotoxicity & Elansary et al., (2020) \\
\hline 11 & $\begin{array}{l}\text { Mangifera } \\
\text { indica }\end{array}$ & Mango & Anacardiaceae & $\begin{array}{l}\text { Antioxidant, anti-inflammatory, radioprotective, antitumor, immune- } \\
\text { modulatory, antiallergic, antidiabetic, anti-bone resorption, mono- } \\
\text { amine oxidase inhibiting, antiviral, antifungal, antibacterial, } \\
\text { antispasmodic, antidiarrheal, antimalarial, antiparasitic lipolytic } \\
\text { properties. }\end{array}$ & Batool et al., (2018) \\
\hline 12 & $\begin{array}{l}\text { Manilkara } \\
\text { zapota }\end{array}$ & Chiku & Sapotaceae & $\begin{array}{l}\text { Antibacterial, hepato-protective, anti-inflammatory, anti-tussive, } \\
\text { antifungal, anti-tumour, and free radical scavenging potential }\end{array}$ & Sharma et al., (2020) \\
\hline 13 & $\begin{array}{l}\text { Momordica } \\
\text { charantia }\end{array}$ & Bitter gourd & Cucurbitaceae & $\begin{array}{l}\text { Antilyyerglycemic, antibacterial, antiviral, antitumor, } \\
\text { immunomodulation, antioxidant, antidiabetic, anthelmintic, } \\
\text { antimutagenic, antiulcer, antilipolytic, antifertility, hepatoprotective, } \\
\text { anticancer and anti-inflammatory activities }\end{array}$ & Jia et al., (2017) \\
\hline 14 & $\begin{array}{l}\text { Moringa } \\
\text { oleifera }\end{array}$ & Drumsticks & Moringaceae & $\begin{array}{l}\text { Antiurolithiatic activity, analgesic, anti-inflammatory, antipyretic, } \\
\text { anticancer, antioxidant, nootropic, hepatoprotective, astroprotective, } \\
\text { antiulcer, cardiovascular, antiobesity, antiepileptic, antiasthmatic, } \\
\text { antidiabetic, antiurolithiatic, diuretic, local anesthetic, antiallergic, } \\
\text { anthelmintic, wound healing, antimicrobial, immunomodulatory, and } \\
\text { antidiarrheal properties }\end{array}$ & $\begin{array}{l}\text { Karadi et al., (2006) } \\
\text { Bhattacharya et al., (2018) }\end{array}$ \\
\hline 15 & $\begin{array}{l}\text { Musa } \\
\text { paradisiaca }\end{array}$ & banana & Musaceae & Antiurolithiatic, antioxidant activity & Panigrahi PN et al., (2017) \\
\hline 16 & $\begin{array}{l}\text { Phyllanthus } \\
\text { emblica }\end{array}$ & $\begin{array}{l}\text { Indian } \\
\text { gooseberry or } \\
\text { amla }\end{array}$ & Euphorbiaceae & $\begin{array}{l}\text { Antidiabetic, hypolipidemic, antibacterial, antioxidant, } \\
\text { antiulcerogenic, hepatoprotective, gastroprotective, and } \\
\text { chemopreventive properties. In treatment of diarrhea, jaundice, and } \\
\text { inflammation. }\end{array}$ & $\begin{array}{l}\text { Krishnaveni \& Mirunalini } \\
(2010) \\
\text { Li et al., (2020) }\end{array}$ \\
\hline 17 & $\begin{array}{l}\text { Plectranthus } \\
\text { amboinicus }\end{array}$ & $\begin{array}{l}\text { Country } \\
\text { Borage }\end{array}$ & Lamiaceae & $\begin{array}{l}\text { Antimicrobial, anti inflammatory, antitumor, wound healing, anti- } \\
\text { epileptic, larvicidal, antioxidant and analgesic activities. Effective } \\
\text { against respiratory, cardiovascular, oral, skin, digestive and urinary } \\
\text { diseases }\end{array}$ & Arumugam et al., (2016) \\
\hline 18 & $\begin{array}{l}\text { Psidium } \\
\text { guajava }\end{array}$ & Guava & Myrtaceae & Antiurolithiatic activity, antioxidant, anti inflammatory activity & $\begin{array}{l}\text { Agarwal \& Varma (2015) } \\
\text { Vasconcelos et al., (2017) }\end{array}$ \\
\hline 19 & $\begin{array}{l}\text { Punica } \\
\text { granatum }\end{array}$ & Pomegranate & Lythraceae & $\begin{array}{l}\text { Antiurolithiatic activity, anti-inflammatory, antibacterial, } \\
\text { antidiarrheal, immune modulatory, antitumor, wound healing and } \\
\text { antifungal }\end{array}$ & $\begin{array}{l}\text { Rathod et al., (2012) } \\
\text { Saced et al., (2018) }\end{array}$ \\
\hline 20 & $\begin{array}{l}\begin{array}{l}\text { Ribes } \\
\text { crispa }\end{array} \\
\end{array}$ & Gooseberry & Grossulariaceae & Antioxidant activity & Laczkó-Zōld et al., (2018) \\
\hline
\end{tabular}


Table 2

\begin{tabular}{|c|c|c|c|c|c|c|c|}
\hline \multirow{2}{*}{$\begin{array}{l}\text { Name of the } \\
\text { Antioxidant } \\
\text { enzymes } \\
\text { (Targets) }\end{array}$} & \multirow{2}{*}{$\begin{array}{l}\text { Name of the } \\
\text { molecules } \\
\text { (Ligands) }\end{array}$} & \multicolumn{3}{|c|}{$\begin{array}{l}\text { Details of H-bond } \\
\text { interaction }\end{array}$} & \multirow{2}{*}{$\begin{array}{l}\text { Atomic } \\
\text { Contact } \\
\text { Energy } \\
\text { (ACE) values } \\
\text { in KJ/mol }\end{array}$} & \multirow{2}{*}{$\begin{array}{l}\text { Gliding } \\
\text { values }\end{array}$} & \multirow{2}{*}{$\begin{array}{c}\text { Amino acid residues of docked } \\
\text { domains }\end{array}$} \\
\hline & & $\begin{array}{c}\text { No. } \\
\text { of } \\
\text { bond }\end{array}$ & $\begin{array}{c}\text { Bond } \\
\text { energy }\end{array}$ & $\begin{array}{l}\text { Bond } \\
\text { length }\end{array}$ & & & \\
\hline \multirow{4}{*}{$\begin{array}{l}\text { Superoxide } \\
\text { dismutase }\end{array}$} & Gallic acid & 2 & -2.35 & 3.12 & -137.22 & -2.74 & Leu 106 , Ile 151 , Cys 111 , Ile 113 \\
\hline & Vanillic acid & 4 & -2.5 & 2.60 & -156.44 & -3.12 & $\begin{array}{l}\text { Ala 1, Leu 106, Cys 111, Ile 113, Cys } \\
111 \text {, Ile } 113\end{array}$ \\
\hline & Rutin & 10 & -2.36 & 2.60 & -349.88 & -6.99 & $\begin{array}{l}\text { Leu } 106 \text {, Ser } 107 \text {, Gly } 108 \text {, Cys } 111 \text {, Ile } \\
113 \text {, Arg } 115 \text {, Ile } 151 \text {, Leu 106, Ser } 107 \text {, } \\
\text { Gly } 108 \text {, Asp } 109 \text {, Cys } 111 \text {, Ile } 113 \text {, Arg } \\
115 \text {, Ile } 151\end{array}$ \\
\hline & 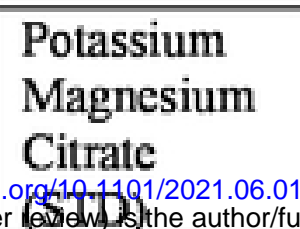 & 4 & -2.5 & 2.65 & $\begin{array}{c}-222.84 \\
\\
\text { pyright holder for this prep } \\
\text { the preporint in perpoetuty. }\end{array}$ & -4.45 & Val 148, Val 7, Lys 9, Gly 147, Val 148 \\
\hline \multirow{4}{*}{ Peroxidase } & Gallic acid ave able & erace & $-2.5^{2}$ & 2.90 & -89.50 & -1.79 & Met 127, Thr 152, Leu 190, Thr 192 \\
\hline & Vanillic acid & 1 & - & - & -116.04 & -2.32 & $\begin{array}{l}\text { Phe } 28 \text {, Ala } 58 \text {, Ala } 62 \text {, Lys } 67 \text {, Pro } 99 \text {, } \\
\text { Phe } 100 \text {, Pro } 101\end{array}$ \\
\hline & Rutin & 8 & $\begin{array}{l}-2.04 \\
-2.5 \\
-2.5\end{array}$ & $\begin{array}{l}3.19 \\
2.63 \\
2.68\end{array}$ & -243.50 & -4.87 & $\begin{array}{l}\text { Arg 174, Leu 190, Thr 192, Met 127, } \\
\text { Val 129, Pro 150, Ala 151, Thr } 152\end{array}$ \\
\hline & $\begin{array}{l}\text { Potassium } \\
\text { Magnesium } \\
\text { Citrate } \\
\text { (STD) }\end{array}$ & 4 & -2.5 & 3.05 & -184.76 & -3.69 & Glu 93, Pro 94, Thr 95, Glu 96, Lys 97 \\
\hline \multirow{4}{*}{ Catalase } & Gallic acid & 9 & $\begin{array}{l}-2.05 \\
-2.26 \\
-2.5\end{array}$ & $\begin{array}{l}3.18 \\
3.14 \\
2.88\end{array}$ & -53.17 & -1.06 & $\begin{array}{l}\text { Gln 52, Tyr 230, Pro } 344 \text {, Ser } 345 \text {, Pro } \\
346 \text {, Gln } 351 \text {, Thr } 422 \text {, Phe } 424 \text {, Val } \\
428\end{array}$ \\
\hline & Vanillic acid & 5 & $\begin{array}{l}-2.06 \\
-2.5\end{array}$ & $\begin{array}{l}2.54 \\
2.87\end{array}$ & -53.80 & -1.07 & $\begin{array}{l}\text { Pro 358, Arg 362, Leu 370, Thr 28, Gly } \\
\text { 30, Asn 32, Val 54 }\end{array}$ \\
\hline & Rutin & 8 & $\begin{array}{l}-2.5 \\
-2.5 \\
-2.27 \\
-2.43\end{array}$ & $\begin{array}{l}2.82 \\
2.63 \\
3.14 \\
2.79\end{array}$ & -217.45 & -4.34 & $\begin{array}{l}\text { His } 363 \text {, Pro } 390 \text {, Arg 362, His 363, Leu } \\
\text { 365, Pro 367, His 363, Arg 364, Pro } 390\end{array}$ \\
\hline & $\begin{array}{l}\text { Potassium } \\
\text { Magnesium } \\
\text { Citrate } \\
\text { (STD) }\end{array}$ & 2 & -1.98 & 3.20 & -78.17 & -1.56 & Glu 66, Arg 67, Arg 169, His 174 \\
\hline \multirow{4}{*}{$\begin{array}{l}\text { Glutathione } \\
\text { S-transferase }\end{array}$} & Gallic acid & - & - & - & -165.42 & -3.30 & Leu 35 , Val 36 , His 40 \\
\hline & Vanillic acid & - & - & - & -176.76 & -3.53 & Val 36, Leu 119 \\
\hline & Rutin & 12 & $\begin{array}{l}-2.40 \\
-2.5 \\
-2.5\end{array}$ & $\begin{array}{l}3.11 \\
2.91 \\
3.07\end{array}$ & -196.14 & -3.92 & $\begin{array}{l}\text { Ala } 103 \text {, Asp } 104, \text { Arg } 107 \text {, Gly } 108, \\
\text { Arg } 239 \text {, Arg 242, Pro 244, Ala 103, } \\
\text { Asp 104, Cys 105, Arg 107, Gly } 108 \text {, } \\
\text { Thr } 109 \text {, Asn } 135 \text {, Arg } 242 \text {, Pro } 244\end{array}$ \\
\hline & $\begin{array}{l}\text { Potassium } \\
\text { Magnesium } \\
\text { Citrate } \\
\text { (STD) }\end{array}$ & 2 & - & - & -251.96 & -5.03 & $\begin{array}{l}\text { Thr 109, Ile 112, Asn 135, Ala 138, } \\
\text { Pro } 244\end{array}$ \\
\hline
\end{tabular}


Table 3:

\begin{tabular}{|c|c|c|c|c|c|c|c|}
\hline \multirow{2}{*}{$\begin{array}{l}\text { Name of the } \\
\text { Metabolic } \\
\text { enzymes } \\
\text { (Targets) }\end{array}$} & \multirow{2}{*}{$\begin{array}{l}\text { Name of the } \\
\text { molecules } \\
\text { (Ligands) }\end{array}$} & \multicolumn{3}{|c|}{$\begin{array}{l}\text { Details of H-bond } \\
\text { interaction }\end{array}$} & \multirow{2}{*}{$\begin{array}{c}\text { Atomic } \\
\text { Contact } \\
\text { Energy }(\mathbf{A C E}) \\
\text { values } \mathrm{KJ} / \mathrm{mol}\end{array}$} & \multirow{2}{*}{$\begin{array}{l}\text { Gliding } \\
\text { Values }\end{array}$} & \multirow{2}{*}{$\begin{array}{l}\text { Amino acid residues of docked } \\
\text { domains }\end{array}$} \\
\hline & & $\begin{array}{c}\text { No. } \\
\text { of } \\
\text { bond }\end{array}$ & $\begin{array}{c}\text { Bond } \\
\text { energy }\end{array}$ & $\begin{array}{l}\text { Bond } \\
\text { length }\end{array}$ & & & \\
\hline \multirow{4}{*}{$\begin{array}{c}\text { Alanine- } \\
\text { Glyoxylate } \\
\text { Aminotransferas } \\
\text { e }\end{array}$} & Gallic acid & 5 & $\begin{array}{l}-2.5 \\
-2.5 \\
-2.5 \\
-2.5 \\
\end{array}$ & $\begin{array}{l}2.87 \\
3.08 \\
2.68 \\
2.76 \\
\end{array}$ & -110.58 & -2.21 & $\begin{array}{l}\text { Ala 210, Leu 211, Ser 275, Gln 282, } \\
\text { Ser 287 }\end{array}$ \\
\hline & Vanillic acid & 2 & $\begin{array}{l}-2.5 \\
-2.5\end{array}$ & $\begin{array}{l}2.99 \\
2.68\end{array}$ & -134.52 & -2.69 & $\begin{array}{l}\text { Ala 210, Leu 211, Asn 212, Leu 278, } \\
\text { Gln 282, Ser 287, His 291 }\end{array}$ \\
\hline & Rutin & 3 & $\begin{array}{l}-2.25 \\
-2.10\end{array}$ & $\begin{array}{l}3.14 \\
3.17\end{array}$ & -302.13 & -6.04 & $\begin{array}{l}\text { Ile 20, Pro 21, Asn 22, Gln 23, Leu } \\
\text { 24, Leu 25, Asn 32, Leu 33, Met } 38\end{array}$ \\
\hline & $\begin{array}{l}\text { Potassium } \\
\text { Magnesium } \\
\text { Citrate } \\
\text { (STD) }\end{array}$ & 1 & - & - & -202.38 & -4.04 & $\begin{array}{l}\text { Leu 163, Thr 191, Arg 292, Pro 314, } \\
\text { Ala 315, Arg 317, Pro } 319\end{array}$ \\
\hline \multirow[t]{5}{*}{$\begin{array}{l}\text { bioRxiv preprint doi: hitps://doli } \\
\text { (which was not certified by pee }\end{array}$} & 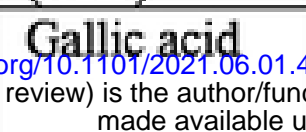 & 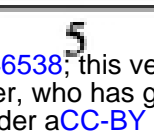 & 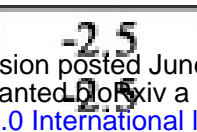 & 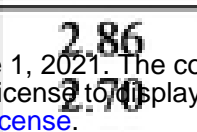 & $\begin{array}{l}\text { pyright hold } 121.82 \\
\text { the preprintis preprint }\end{array}$ & -2.43 & $\begin{array}{l}\text { Ala 92, Thr 95, Thr 96, Pro 131, His } \\
132 \text {, Trp 425, Glu 122, Met } 123\end{array}$ \\
\hline & & & $\begin{array}{l}.0 \text { Intéñational } \\
-2.09\end{array}$ & 2.78 & & & \\
\hline & Vanillic acid & 4 & -2.34 & 2.81 & -130.17 & -2.60 & $\begin{array}{l}\text { Ala 92, Thr 96, Pro } 131 \text {, His } 132, \text { Tr } \\
425 \text {, Glu } 122 \text {, Met } 123 \text {, Val } 128\end{array}$ \\
\hline & Rutin & 8 & $\begin{array}{l}-2.39 \\
-2.06\end{array}$ & $\begin{array}{l}3.12 \\
3.18\end{array}$ & -211.63 & -4.23 & $\begin{array}{l}\text { Thr } 95 \text {, Pro } 131 \text {, His } 132, \text { Cys } 133, \\
\text { Arg } 160 \text {, Arg } 282 \text {, Val } 113 \text {, Gln } 116 \text {, } \\
\text { Gly } 118 \text {, Met } 123 \text {, Asp } 124\end{array}$ \\
\hline & $\begin{array}{l}\text { Potassium } \\
\text { Magnesium } \\
\text { Citrate } \\
\text { (STD) } \\
\end{array}$ & 3 & -2.05 & 3.18 & -154.10 & -3.08 & $\begin{array}{l}\text { Pro 246, Lys 251, Ala 263, Arg 408, } \\
\text { Met } 409\end{array}$ \\
\hline \multirow{4}{*}{$\begin{array}{l}\text { D-glycerate } \\
\text { dehydrogenase }\end{array}$} & Gallic acid & 7 & $\begin{array}{c}-2.35 \\
-2.5 \\
-2.5 \\
-2.09\end{array}$ & $\begin{array}{l}2.58 \\
3.08 \\
3.04 \\
2.55\end{array}$ & -83.16 & -1.66 & $\begin{array}{l}\text { Thr 105, Thr 238, Ala 239, Val 265, } \\
\text { His 287, Ser 290, Trp } 135\end{array}$ \\
\hline & Vanillic acid & 3 & -2.20 & 2.56 & -90.91 & -1.81 & $\begin{array}{l}\text { Trp 135, Ile } 77 \text {, Val } 101 \text {, Thr } 105 \text {, } \\
\text { Thr 238, His } 287 \text {, Ser } 290\end{array}$ \\
\hline & Rutin & 7 & $\begin{array}{l}-2.45 \\
-2.17\end{array}$ & $\begin{array}{l}3.10 \\
3.16\end{array}$ & -261 & -5.22 & $\begin{array}{l}\text { Ile 77, Pro 98, Val 101, Thr 102, Thr } \\
\text { 105, Ile 158, Asn 210, Thr 238, Ala } \\
239 \text {, Arg 240 }\end{array}$ \\
\hline & $\begin{array}{l}\text { Potassium } \\
\text { Magnesium } \\
\text { Citrate } \\
\text { (STD) }\end{array}$ & 5 & $\begin{array}{l}-2.5 \\
-2.5\end{array}$ & $\begin{array}{l}2.90 \\
2.78\end{array}$ & -105.07 & -2.10 & $\begin{array}{l}\text { Pro 133, Gly 134, Trp 135, Glu 136, } \\
\text { Trp 9, Lys 33, Asn 54, Pro } 270\end{array}$ \\
\hline \multirow{4}{*}{$\begin{array}{c}\text { Lactate } \\
\text { dehydrogenase }\end{array}$} & Gallic acid & 3 & -2.02 & 3.19 & -43.36 & -0.86 & $\begin{array}{l}\text { Arg } 98 \text {, Gln } 99 \text {, Arg } 105 \text {, His } 192, \\
\text { Ala 237, Ile } 251\end{array}$ \\
\hline & Vanillic acid & 2 & - & - & -61.57 & -1.23 & $\begin{array}{l}\text { Asn 20, Leu 43, Ala 44, Asp 45, Asn } \\
\text { 20, Leu 43, Ala 44, Met } 263\end{array}$ \\
\hline & Rutin & 11 & $\begin{array}{l}-2.5 \\
-2.5\end{array}$ & $\begin{array}{l}2.71 \\
2.66\end{array}$ & -250.63 & -5.01 & $\begin{array}{l}\text { Val } 30 \text {, Gly } 96 \text {, Ala } 97 \text {, Arg } 98 \text {, Ser } \\
\text { 136, Asn 137, Pro } 138 \text {, His } 192 \text {, Ala } \\
237 \text {, Gly } 245 \text {, Tyr } 246 \text {, Thr } 247\end{array}$ \\
\hline & $\begin{array}{l}\text { Potassium } \\
\text { Magnesium } \\
\text { Citrate } \\
\text { (STD) } \\
\end{array}$ & 3 & -2.5 & 2.91 & -109.89 & -2.19 & $\begin{array}{l}\text { Leu 266, Arg 267, Pro 74, Tyr 171, } \\
\text { Glu 175, Val 179, Pro } 181\end{array}$ \\
\hline
\end{tabular}



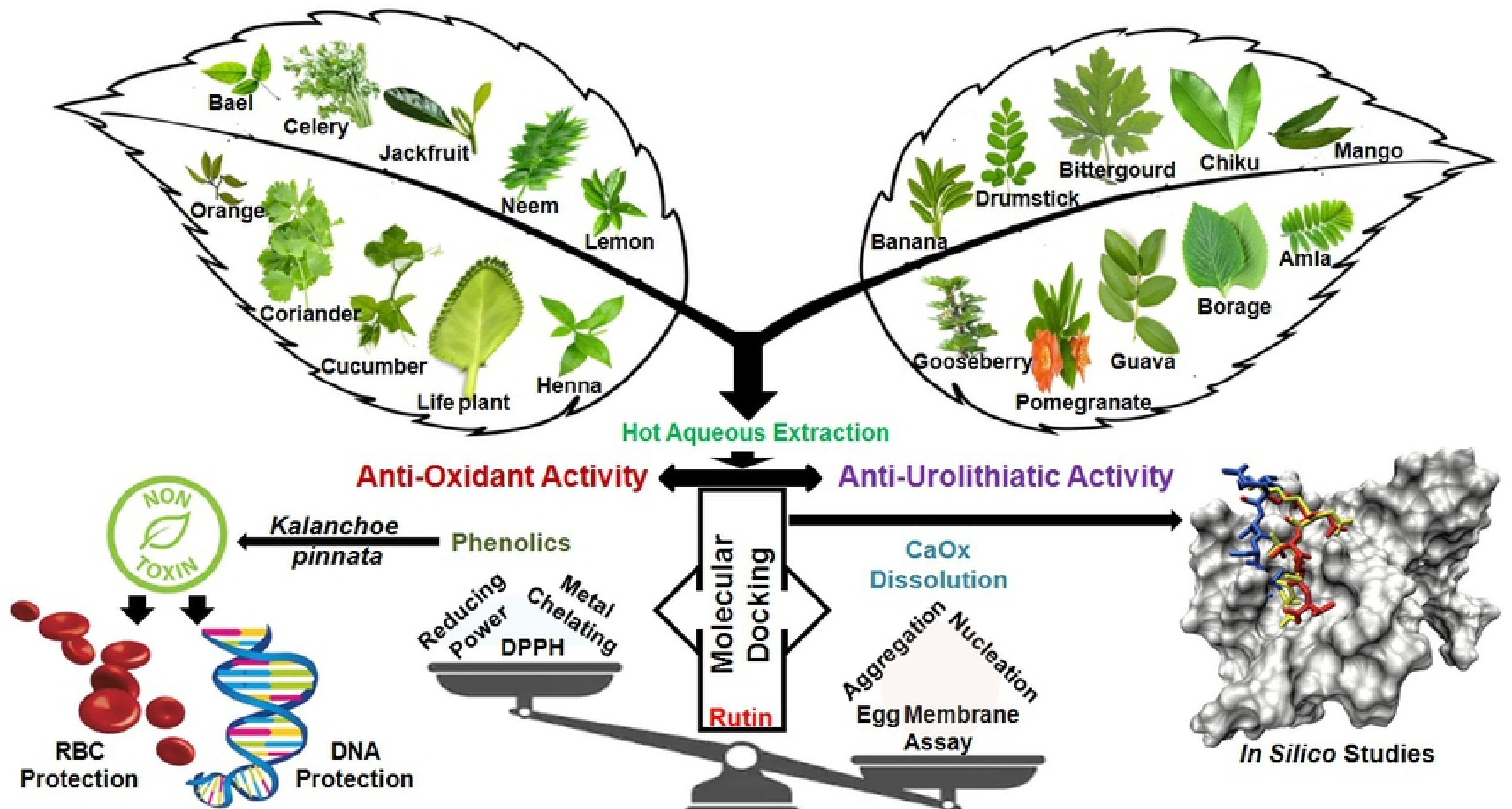

Hot Aqueous Extraction

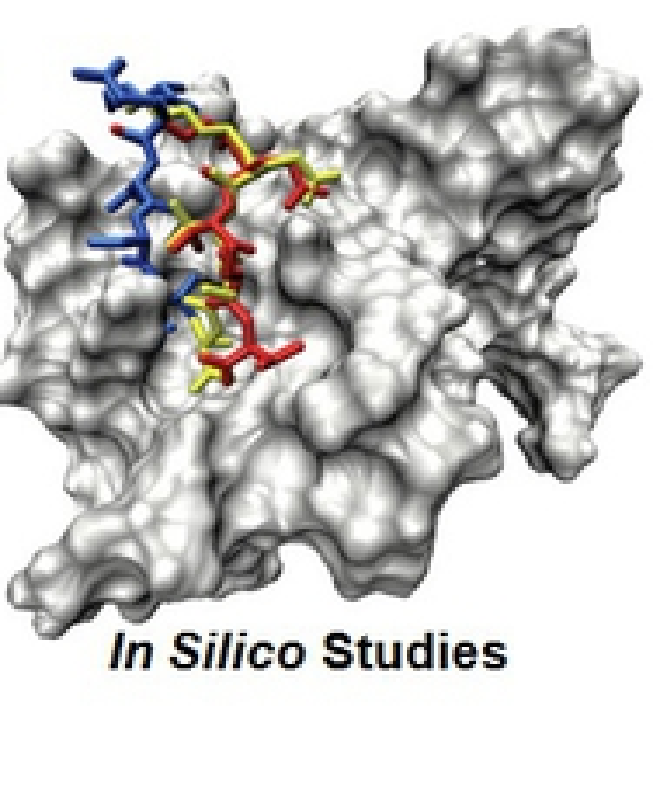
Graphical Abstract 
$\mathbf{a}$

a

$j=\frac{10}{2} \sum^{2}=$

e

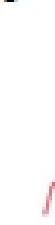

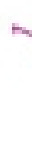

\rangle

i

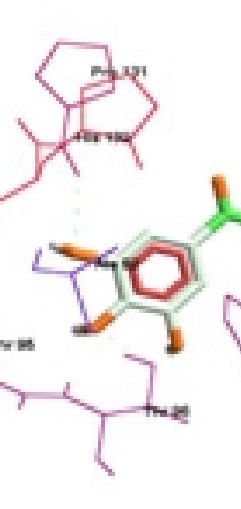

(1)

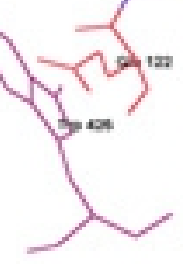

j

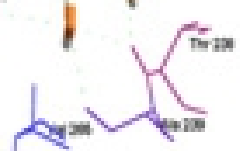

or

\begin{tabular}{|l|l}
\hline $\mathbf{k}$ & $\mathbf{k}$ \\
\hline
\end{tabular}

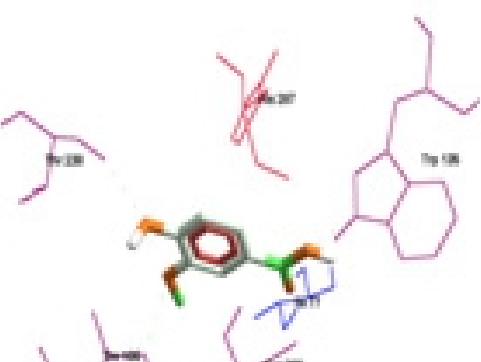

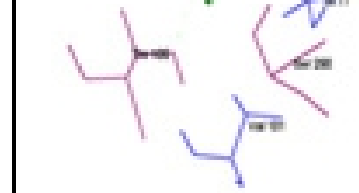

$\sum_{n \rightarrow \infty}$

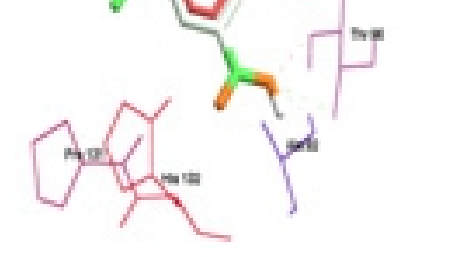

c

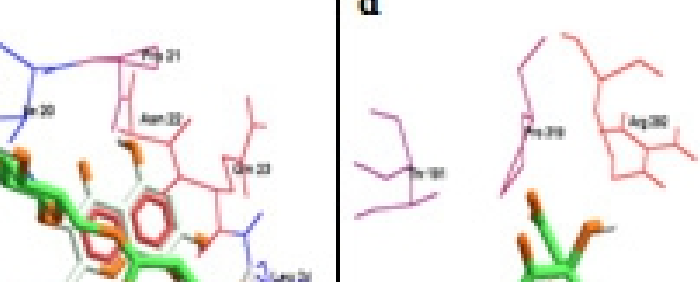

$\underbrace{2}_{-\infty}>$

\begin{tabular}{l|l}
$\mathrm{g}$ \\
\hline
\end{tabular}

(3) \begin{tabular}{|l|l}
\hline$g$ & h
\end{tabular}

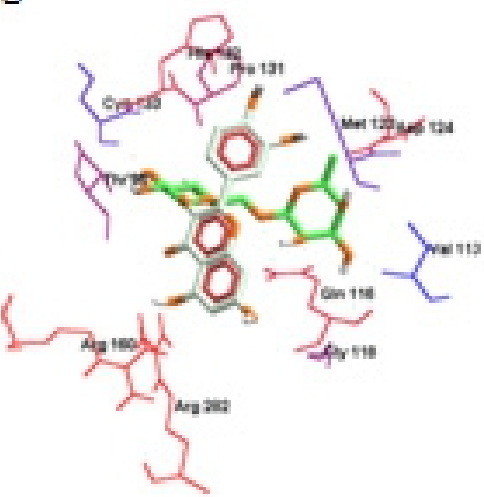

$K=\underbrace{}_{-\infty}$

h

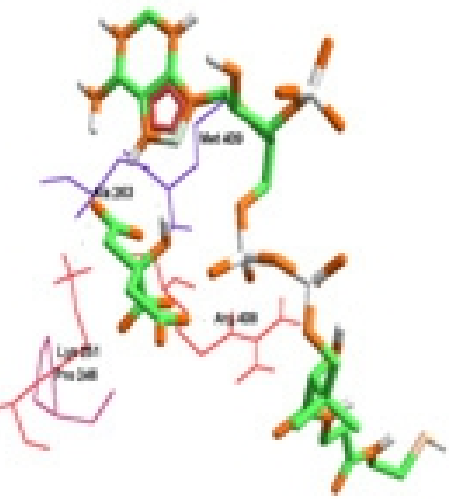

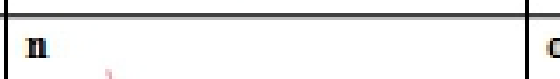

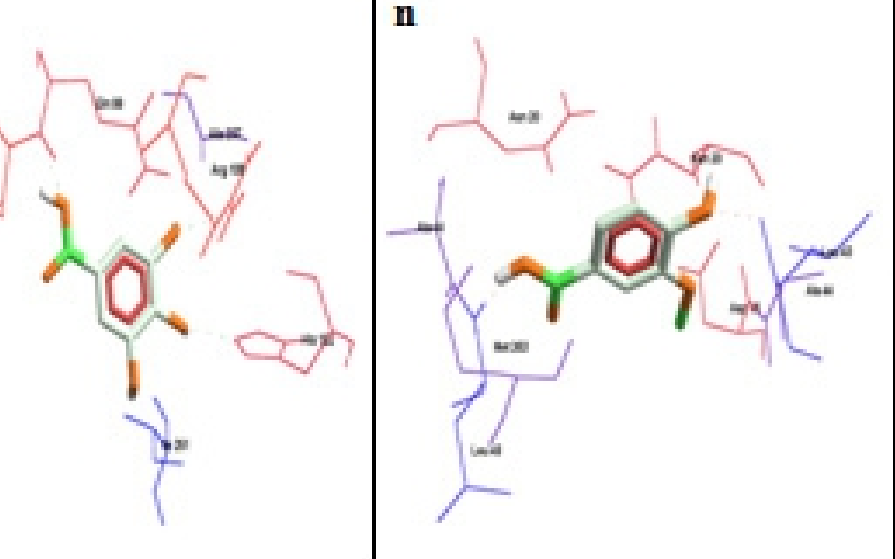

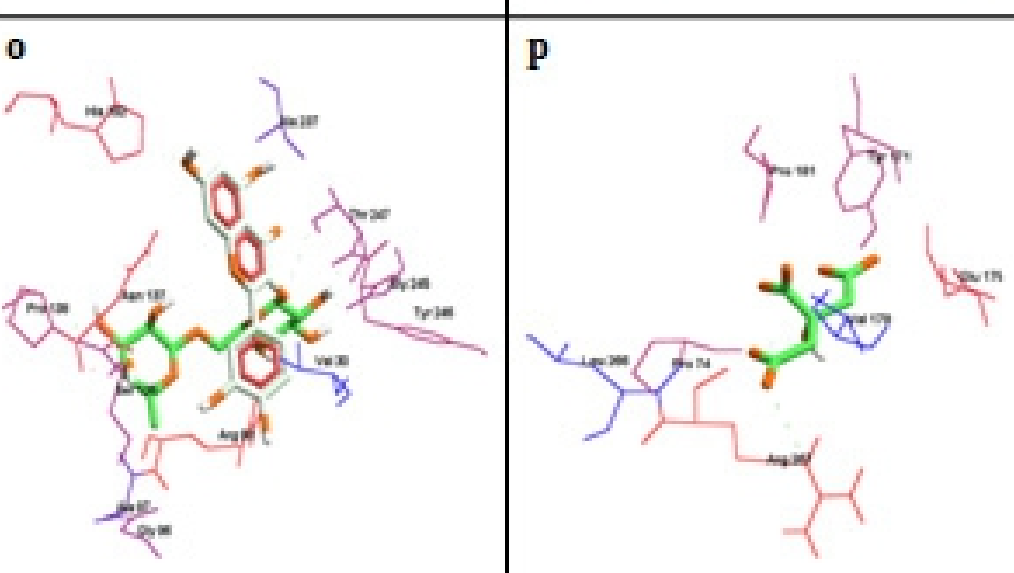

\section{Figure 8}




\section{Figure Legends:}

Figure 1: Quantitative estimation of polyphenolic content of 20 selected botanicals.

Figure 2: Antioxidant radical scavenging assay of the 20 selected botanicals at $5 \mu \mathrm{g} / \mathrm{mL}, 15$ $\mu \mathrm{g} / \mathrm{mL}$ and $25 \mu \mathrm{g} / \mathrm{mL}$ respectively. (A): DPPH assay, (B): Metal ion chelating assay and (C): Reducing power assay.

Figure 4: In vitro experimental assessment of anti-lithiatic activity of top 5 best phytocontributors using chicken egg membrane model with cystone as standard herbal drug.

Figure 5: (A): Dose-dependent assessment of KP extract using nucleation assay. (B): Dosedependent assessment of KP extract using aggregation assay.

Figure 6: Panel A: Evaluation of KP extracts on erythrocyte morphology by RBC protection assay. (a): control-RBC, (b): RBC+PBS ( $\mathrm{pH} 7.4$ ), (c): RBC plus oxidant, (d): RBC plus gallic acid (std $10 \mu \mathrm{g} / \mathrm{mL}$ ), (e): RBC plus $25 \mu \mathrm{g} / \mathrm{mL}$ of $\mathrm{KP}$ and oxidant after $1 \mathrm{~h}$ of incubation. Panel B: Electrophoretic analysis of DNA protection assay by KP extracts. Lane 1: native DNA, Lane 2: oxidised DNA, Lane 3: Gallic acid (std $10 \mu \mathrm{g} / \mathrm{mL}$ ), Lane 4: Cystone (std $10 \mu \mathrm{g} / \mathrm{mL}$ ), Lane 5: KP extract $(5 \mu \mathrm{g} / \mathrm{mL})$ and Lane 6: KP extract $(25 \mu \mathrm{g} / \mathrm{mL})$.

Figure 7: HPLC profiling of the aqueous KP extract containing the phytochemicals.

Figure 8: In silico molecular docking of KP phytochemical ligands on antioxidant enzymes.

Footnotes for Figure 8: Docked images of antioxidant enzymes: (a) Superoxide dismutase docked with Gallic acid, (b) Superoxide dismutase docked with Vanillic acid, (c) Superoxide dismutase docked with Rutin, (d) Superoxide dismutase docked with Potassium-Magnesium Citrate, (e) Peroxidase docked with Gallic acid, (f) Peroxidase docked with Vanillic acid, (g) Peroxidase docked with Rutin, (h) Peroxidase docked with PotassiumMagnesium Citrate, (i) Catalase docked with Gallic acid, (j) Catalase docked with Vanillic acid, (k) Catalase docked with Rutin, (I) Catalase docked with Potassium-Magnesium Citrate, (m) Glutathione S-transferase docked with Gallic acid, (n) Glutathione S-transferase docked with Vanillic acid, (o) Glutathione S-transferase docked with Rutin and, (p) Glutathione S-transferase docked with Potassium-Magnesium Citrate. 
Figure 9: In silico molecular docking of KP phytochemical ligands on calcium oxalate regulating metabolic enzymes.

Footnotes for Figure 9: Docked images of metabolic enzymes: (a) Alanine glyoxylate aminotransferase docked with Gallic acid, (b) Alanine glyoxylate aminotransferase docked with Vanillic acid, (c) Alanine glyoxylate aminotransferase docked with Rutin, (d) Alanine glyoxylate aminotransferase docked with PotassiumMagnesium Citrate, (e) Oxalyl CoA decarboxylase docked with Gallic acid, (f) Oxalyl CoA decarboxylase docked with Vanillic acid, (g) Oxalyl CoA decarboxylase docked with Rutin, (h) Oxalyl CoA decarboxylase docked with Potassium-Magnesium Citrate, (i) D- glycerate dehydrogenase docked with Gallic acid, (j) Dglycerate dehydrogenase docked with Vanillic acid, (k) D- glycerate dehydrogenase docked with Rutin, (l) Dglycerate dehydrogenase docked with Potassium-Magnesium Citrate, (m) Lactate dehydrogenase docked with Gallic acid, (n) Lactate dehydrogenase docked with Vanillic acid, (o) Lactate dehydrogenase docked with Rutin and, (p) Lactate dehydrogenase docked with Potassium-Magnesium Citrate. 
Table Legends:

Table 1: List of selected 20 botanicals screened for anti-oxidant and anti-urolithiatic activity.

Table 2: Structure-activity relationship (SAR) of potent ligands from KP with antioxidant enzymes.

Table 3: Structure-activity relationship (SAR) of potent ligands from KP with calcium regulating metabolic enzymes.

\section{Table Legends}

